\section{CALCULUS IN THE URETER.}

BY HENRY MORRIS, F.R.C.S. ENG., SENIOR SURGEON TO THE MIDDLESEX HOSPITAL; MEMBER OF THF COUNCIL, AND OF THE COUR'T OF EXAMTNERS OF THIB ROYAL COLLEGE OF SURGEONS OF ENGLAND.

BY ureteral calculus, or calculus in the ureter, is meant a calculus which, formed in the kidney, has become impacted in the ureter. Renal calculi, while yet small, and especially if their surfaces are smooth or if the ureter has been previously dilated, frequently pass along the ureter to the bladder without causing any trouble. On the other hand, their passage is in some cases attended by the most severe suffering and the impaction of a stone so small as to weigh less than two grains may completely destroy the kidney (Fig. 1) or

$$
\text { FIG. } 1 \text {. }
$$

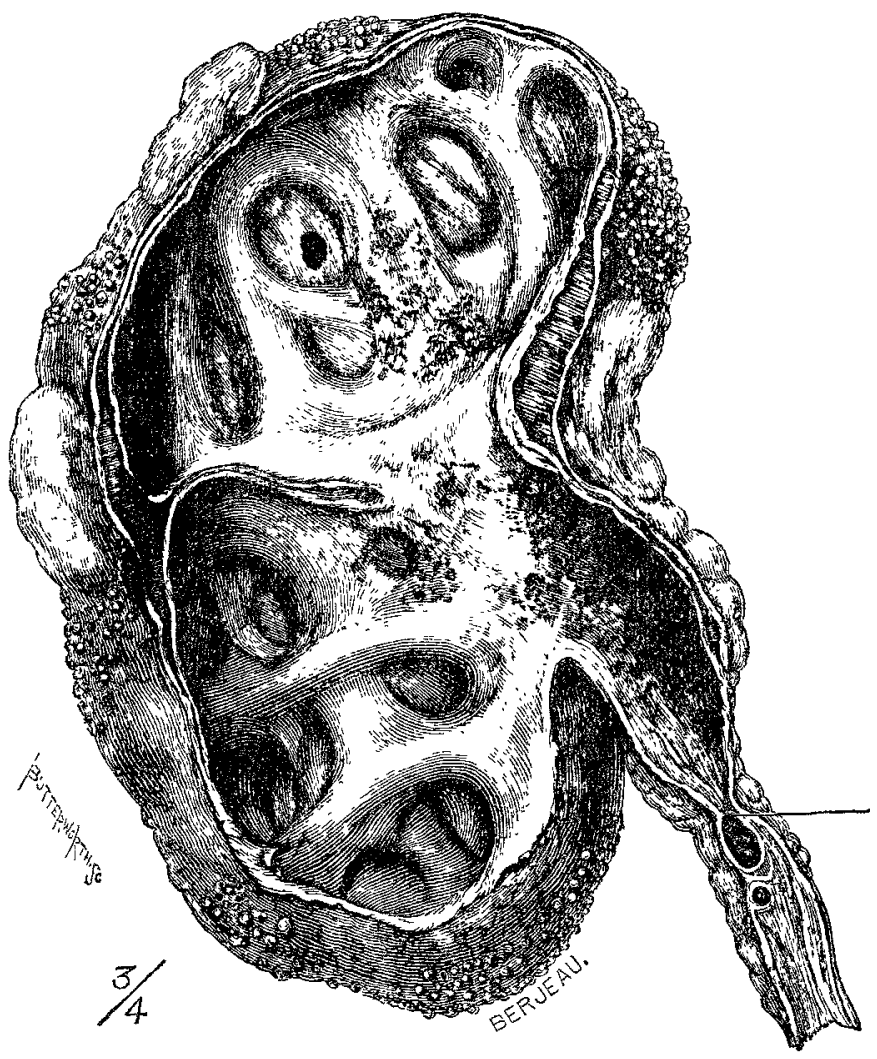

A pyonephrotic kidney due to calculi of minute size blocking the upper end of the ureter (author's case).

excite symptoms of the most violent character ending even in fatal collapse. If the stone reaches the bladder all distress ceases, at any rate for a time, and it either remains in the bladder and becomes a nucleus for a larger concretion or later becomes impacted in the urethra, or, more happily, is discharged out of the body with the urine. In males it is very commonly retained in the bladder or, but far less frequently, in the urethra. In women, if it reaches the bladder it almost always escapes by the urethra, and this explains the great difference in the frequency with which vesical calculus is met with in the two sexes. This difference does not exist in renal and ureteral calculus. On of 47 cases of ureteral calculus neferred to in the accompanying table 27 were in females, 18 were in males, and in two cases the sex is not stated.

\section{ETTOLOGY.}

Stones in the ureter descend from the kidney and their impaction is due to their volume or their irregularity of shape and roughness of surface. In the first place, the spasmodic contraction of the muscular coats of the ureter, provoked by their presence, and at a later period the inflammatory swelling and ulceration of the mucous membrane add to the difficulty of their progress towards the bladder. Should the irritation lead to thickening, rigidity, or stenosis at the seat of impaction the stone will remain permanently fixed.

Calculous concretions formed primarity in the ureter are very rare. When they occur they are composed of phosphatic salts deposited above a stricture, or upon an ulcer of the ureter, or upon a foreign body within the ureter such as a catheter en demeure.

Duration of impaction.-When a calculus becomes impacted in the ureter it may romain there if not extracted by the surgeon for an indefinite time or altogether. It must not, however, be inferred when a stone is discovered in the ureter that it has been there for the whole or the greater part of the time since the onset of the symptoms. It may have been in the kidney for the greater part of the time. With our present knowledge it is impossible in most cases to diagnose between a stone or other cause of obstruc. tion in the renal pelvis and the same condition in the ureter.

Negative explorations of the kidney followed after a time by the discharge per urethram of a small calculns afford us some evidence as to the length of time during which a calculus may remain in the ureter before being passed naturally, though this evidence is not precise as to the exact duration of impaction. During the 19 years since my first renal operation $I$ have in six cases explored without finding a stone in the kidney, though in each case a stone must have been present in the ureter at the time of the operation. Five out of six of these patients subse. quently passed a calculus and one died more than 12 months after the operation and a stone was found at the post-mortem examination impacted near the vesical end of the ureter on the side which had been explored. In one of the five surviving cases two small calculi were passed during convalescence. In another the right kidney was explored on March 26th, 1890, and a small renal calculus was passed in June, 1891-i.e., after an interval of 15 months from the exploration. Then followed a period of 18 months of complete immunity from symptoms, but in January, 1893, the patient was seized with intense pain and hæmaturia and this attack was followed by other similar attacks up to Dec. 6th, 1897, when I again explored the same kidney and removed a large calculus from the renal pelvis and at the same time performed uretero-lithotomy for a small calculus which was completely blocking the ureter at a point abont one and a half inches above the brim of the bony pelvis (No. 40 in the subjoined list). From the large size of the stone which occupied the renal pelvis it is certain that the stone in the ureter must have been lodged there for many months at least. The kidney was greatly disorganised. In each of the three other cases the kidney was moveable; complete exploration was made of the kidney with negative results and yet a calculus was passed by each patient, attended by pain on the side operated upon, at periods of nine months, thirteen months, and five and a half montbs respectively after the operation. There is good reason to believe that in each of these three cases the kidney afterwards resumed its function perfectly.

In all these six cases the kidney was taken out upon the loin, inspected, and palpated; in five of them the kidney was opened along its convex border and a most thorough exploration was made with the finger within the organ. It is not possible that the calculus could have been missed had it been in the kidney or infundibulum at the time of explora tion. From the continuance of the same symptoms after as before the exploration and the complete and lasting relief which followed the passing of the stone there is no escape from the conclusion that the stone was impacted in the ureter at the time of the exploration. Some time before the last of these cases occurred I had commenced what is now an invariable rule with me-namely, sounding the ureter in its whole length before completing the operation. In this case I detected an obstruction in the ureter some distance below the brim of the bony pelvis, but for reasons which I thought sufficient at the time, and which I need not here mention, I did not explore the ureter at the seat of obstruction, though it would have been better if I had done so. After five and a half months, having in the interval suffered repeated attacks of severe pain over this spot, the patient passed a small ovoid calculus (Fig. 2) and he has been quite well ever since.

FIG. 2.

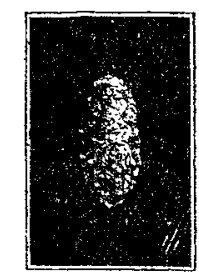

Calculus impacted in the pelvic part of the ureter and subsequently passed naturally passer case).

Facts of this kind inform us that a calculus may remain in the ureter for a long time and after escaping may, as we know from the results of various experiments and from abundant clinical experience, leave the obstructed kidney still capable of discharging its functions provided the obstruction has not been complete. 
Position of impaction.-It is a matter of great importance from a surgical point of view to know at what points in the ureter impaction occurs. In the normal ureter the smallest diameters are found, first at a point about five or seven centimetres (from two to two and a half inches) from the hilum of the kidney, and one or two centimetres below the commencement of the ureter; secondly, where the ureter enters the wall of the bladder, and especially at its termination on the mucous surface of the bladder; and thirdly, there is another but a slighter marrowing (in three out of five subjects) where the ureter crosses the brim of the bony pelvis. It is at one or other of these points that calculi are more usually arrested, but they may become lodged at other points (Fig. 3).

In some of the recorded cases of uretero-lithotomy the

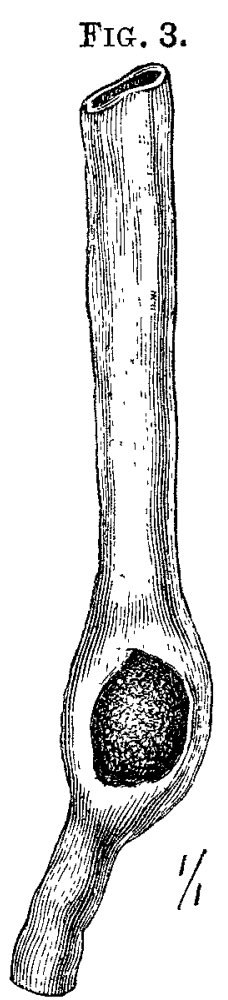

Oval calculus impacted in the ureter three inches Renal pelvis was dilated. Renal substance was normal. Westminster Hospital Museum.

three cases death was caused by uræmia. In the twelfth case the lower opening of the right ureter was entirely obliterated and three calculi were lodged in separate compartments of the ureter, formed one above the other by constricting bands on its inner wall; the largest stone was situated in the upper third of the ureter and was about three inches long and three-quarters of an inch in diameter. In some post-mortem cases the ureter has been found filled, or nearly filled, from end to end with calculi. Wilmot ${ }^{2}$ gives a case of suppurating solitary kidney with a calculus blocking the ureter.

Position of inepacted calculi found at operations. - I have tabulated 46 cases in which an operation was completed on account of a calculus impacted in the ureter. The seat of impaction is stated in 44 of them. In 19 it was within two inches of the kidney, in 15 just before or where passing through the vesical wall, and in 11 somewhere about the level of the brim of the true pelvis; in three of the 11 cases the situation of the stone was below the brim, in two on the brim, and in five just above the brim; in the remaining case the description given is "a stone was found half-way down the ureter." In one case the position of impaction is not stated. In one of $m y$ own cases in which a stone was at the upper end a second calculus was impacted four inches lower down.

It is a noticeable fact that 12 out of 15 cases where the impaction was at the lower end of the ureter occurred in women, and no case has been noted of ureterolithotomy in the male for stone impacted in this situation. I have not been able to ascertain the sex of Ceci's patient. In Rawdon's case a stone was felt by the rectum in the

1 Transactions of the Pathological Society of London, vol. xiii., p. 47. 2 Brit. Med. Jour., Nor. 24 th, 1883

lower part of the left ureter of a boy close to the bladder orifice, and though not removed by operation was verified by post-mortem examination. In two cases in the subjoined table, in which a stone impacted near the bladder led to nephrectomy, the patients were males, one 37 and the other 38 years of age. Spencer Wells reports a case of urinary calculus of the size of a bean which had formed an abscess about the prostate and passed into the rectum direct from the ureter. Agnew relates a case, presumably of a boy, whom he cut for stone in the bladder; the left ureter was enormously dilated and packed with calculi of considerable size, two of which at an interval of three months escaped into the bladder and were removed by vesical lithotomy. Mr. F. W. Gordon of Auckland (New Zealand) sent me notes of a case of sudden death in a man after the introduction of a catheter into the bladder. One kidney was enlarged, the other was a small sac, weighing only three drachms, and its ureter was obliterated at the vesical extremity, presumably due to the lodgment of a renal calculus which ultimately had been passed per urethram.

Characters of Ureteral Calculi.

As we should expect, remembering their origin in the kidney, ureteral calculi differ in size, form, and composition. Some are composed of uric acid and others of the urates; others, again, of calcium oxalate or phosphates. They vary much in volume and number. Fig. 4 shows both ureters from the same individual packed with smooth calculi.

FIG. 4.

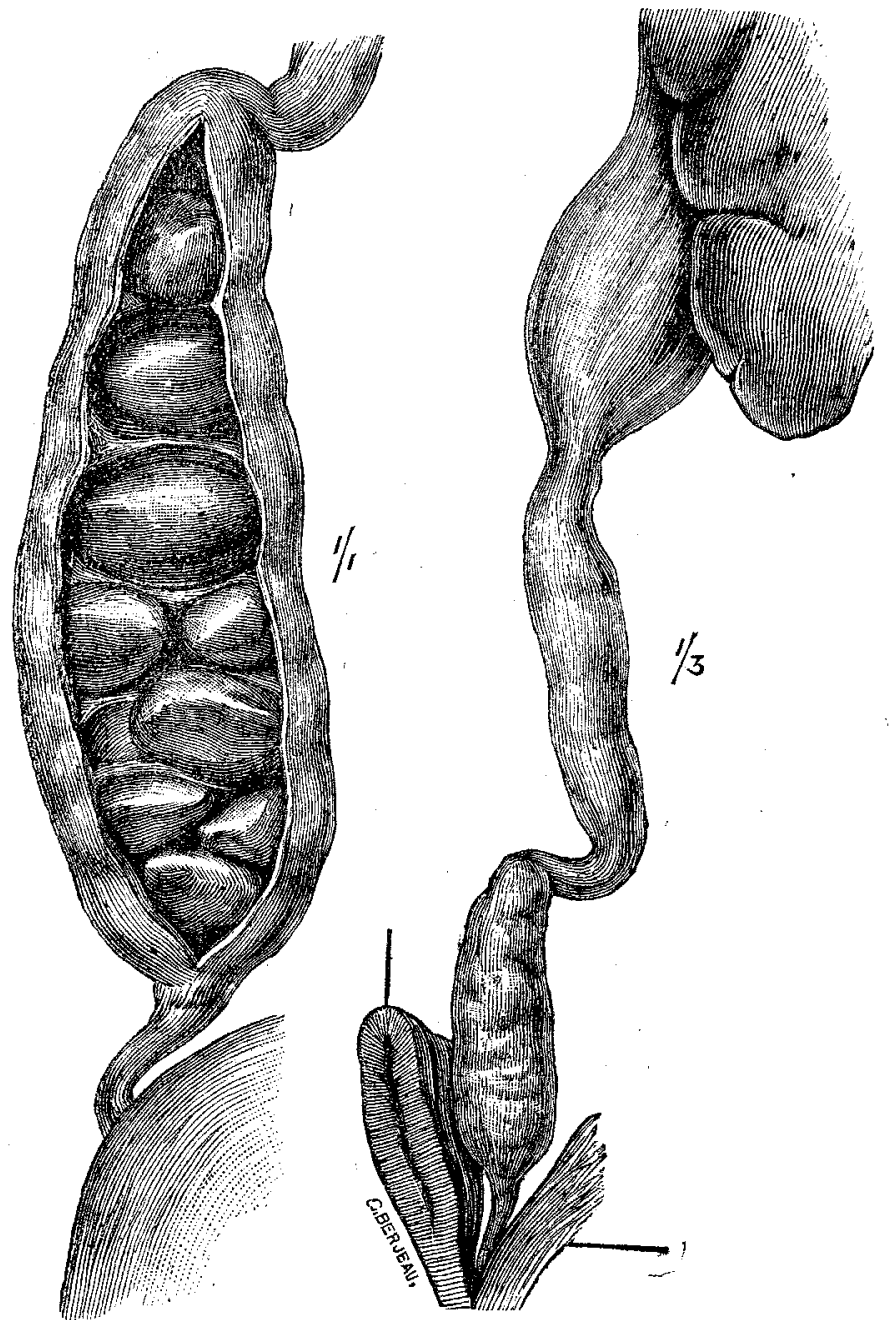

Ureters packed with calculi. Middlesex Hospital Museum.

Roberts ("Urinary and Renal Diseases ") relates a case in which a single stone like a hemp-seed, weighing one and a third grains, and another in which a round uric acid stone of the size of a small pea and weighing one and $a$ half grains killed their victims. Usually their size does not exceed that of a cherry-stone, a horse-bean, or a date-stone. They are often ovoid and elongated but sometimes more nearly spherical. Those which are prolonged into the ureter from the renal pelvis are sometimes hammer-shaped. If other calculi have been or are in the renal pelvis the one blocking the ureter may be angular or faceted (Fig. 5). They may be faceted if two or more are lodged in contart with one another in the 
ureter itself (Fig. 6). If they remain long in the ureter they may increase by superposition of fresh salts from the urine both at their extremities and upon their surface. In some instances instead of a definite calculus there bas been sound a soft mortar-like calculous mass. Their surface is smooth and even polished if of uric acid or the urates, rough and often sparkling with clear beautiful crystals if of phosphate of lime, and minutely but roughly tuberculated or covered with sharp amber-coloured or brownish or yellowishblack points if of calcium oxalate. I have operated on a case where a small rough calculus of calcium oxalate was actually fixed by its processes in the walls of the ureter and required to be dug out before it could be removed. Some

\section{FIG. 5.}

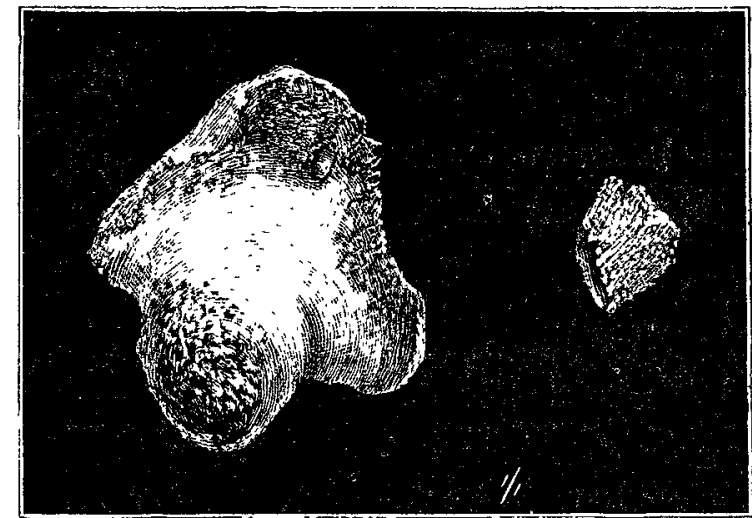

Calculi removed from Case No. 40 in the table, the larger from the renal pelvis, the smaller from the ureter four inches below the renal pelvis.

rough-surfaced phosphatic calculi may be as firmly fixed. The other varieties of stone, though they may be tightly compressed by them, are not adherent to the ureteral walls. Urine may travel past the calculus and make a gutter-like depression on its surface when the ureter does not tightly invest it. Some calculi move like a ball-valve from the renal pelvis into the ureter and back again. Others when they have reached the lower end may project through the ureteral orifice into the bladder.

\section{DiAgNosis.}

Unless a calculus in the ureter can be felt through the abdominal parietes, the rectum, the vagina, or the bladder, its precise location cannot be ascertained except by an exploratory operation.

In most of the cases in which the stone has been impacted near the renal end of the ureter it has been discovered by a digital examination of the ureter at the time of exploring the kidney and generally when no stone has been present in the kidney itself. In one of my cases a stone was

FIG. 6.
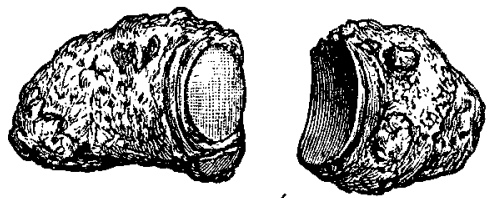

\%

Two faceted calculi which were impacted in the ureter against one another. Westminster Hospital Museum.

ascertained to be lodged in the ureter about one and a half inches above the brim of the bony pelvis by probing the ureter immediately after a large stone had been extracted from the kidney (No. 40 in the subjoined list). It was removed by prolonging the lumbar incision downwards and forwards towards the groin and exposing the ureter at the site at which the ureteral bougie met with a complete obstruction. This case affords a striking illustration of the value and importance of sounding the ureter throughout its extent before concluding an operation even when one or more calculi have been found and removed from the kidney.

The intra-peritoneal exploration has revealed the presence of a calculus in the ureter in a few cases and has been adopted for very different reasons in each case. Thus in Cullingworth's case the calculi were felt per vaginam and mistaken for diseased ovaries ; in Lane's case the kidney had been explored from the loin some months before without result so far as finding a stone or relieving the symptoms; and in Hall's case, though the symptoms pointed to the kidney as much as to the ureter as being the seat of the calculus, an exploratory laparotomy was performed as a preliminary diagnostic precaution. Hall's order of procedure is not to be recommended. In a word, when the symptoms clearly indicate the side to attack and there is no indication by rectal examination in the male or raginal examination in the female that the stone is impacted in the lower end of the ureter, or by palpating the abdomen that it is on the brim of the bony pelvis, renal exploration and sounding the ureter through the loin is the proper course to follow. The ureter can be afterwards exposed lower down, if need be, by prolonging the incision in the lumbo-ilio-inguinal line.

From caloulus in the kidney.-When it is remembered bow uncertain and inconstant the symptoms of stone in the kidney may be, and in how many cases they are not referred to the kidney at all but to some point along the course of the ureter or to the bladder, the ovary, the testicle, or to some other organ, a correct diagnosis of stone in the ureter is not to be frequently expected. Moreover, in many cases of ureteral calculus there are other calculi present in the renal pelvis or calyces. The symptoms produced by a calculus impacted in the ureter simulate those of a stone in the kidney itself, so that in nine out of 11 cases of ureterolithotomy an operation was undertaken under the conviction of finding a stone in the kidney; and the converse is equally true, that the symptoms caused by renal calculus siniulate those of impacted ureteral calculus. The seat of pain and the point of greatest tenderness on pressure in some cases of stone in the kidney are in the course of the ureter and not just below the eleventh or twelfth rib in front, or at the outer edge of the erector spinæ mass behind, as classically they should be. Lumbar exploration alone can clear up the diagnosis.

When the stone is situated high up in the ureter near the renal pelvis it is impossible by clinical symptoms to decide whether it is in the kidney or ureter until it has been detected by palpation through the lumbar wound; but this is of no moment because it is impossible without exposing the lower part of the kidney to remove a calculus from this part of the duct by the extra-peritoneal method. The intraperitoneal operation in such cases is to be absolutely condemned.

When the stone is impacted lower down its exact position can be ascertained by the ureteral bougie passed through an opening in the renal pelvis, and if one be found within the lower abdominal or upper pelvic part of the ureter in the female or in any part of its lower course in the male the calculus can be removed by the extra-peritoneal method after prolonging the lumbar incision forwards and downwards.

When in the female the stone is impacted below where the ureter leaves the pelvic wall, but still at a distance of from three or two and a half inches from the bladder, its position can be diagnosed by ureteral sounding from the lumbar wound, though the best way to extract it is by the sacral route. Ureteral catheterism upwards from the bladder has been recommended, but though this may detect an obstruction and localise its situation it cannot differentiate stone from stricture of the ureter.

From encysted vesical calculus. - In an article on calculus impacted in the ureter published in 1884 " I stated: "It is quite an ancient question in diagnosis whether some of the cases of encysted vesical calculus are not really instances of renal calculus impacted in the lower end of the ureter." It was a subject of discussion in the time of Abraham Vater and Littré (1702); and Morgagni, Collet, Le Dran, Desault, Deschamps, and Chas. Monod have since taken part in it.

Calculi which have reached the vesical end of the ureter failing to enter the cavity of the bladder may become propelled through the side of the ureter and between the coats of the bladder towards the cervix of the bladder; and thus, endeavouring to make a new passage for themselves, may form a sac beneath the mucous membrane of the bladder. Such a sac may present at a spot some little distance from the mouth of the ureter and may or may not ultimately ulcerate or rupture into the bladder cavity. This sac might either have a channel opening into the lowest part of the ureter (as seen by Littré) or the passage from the ureter to

3 American Journal of the Medical Sciences, October, 1884, p. 464 et seq. 
the sac might become shut off by adhesions; in either case it will be completely closed towards the bladder unless the mucous membrane has ulcerated or ruptured over the calculus. It is, of course, possible that such a shut sac, like a prolapsed ureter, might form a pendulous vesical tumour. The diagnosis between a stone impacted in the lower end of the ureter, on the one hand, and on the other a stone encysted in a sac formed in the manner just described, or a stone encysted in an ordinary sacculus of the bladder, might in some instances be made by observing the position of the swelling. A stone impacted in the ureter just above the ureteral orifice may be partly projecting at the ureteral orifice, but if not will have the direction and situation of the intervesical section of the ureter. A stone contained within a sac formed by the bulging or rupture of the ureteral wall and the separation of the coats of the bladder will have a situation between the mouth of the ureter and the urethral opening of the bladder. A stone encysted in an ordinary vesical sacculus may be situated at any part of the bladder-the lower, the middle, or the upper part. The ureteral orifice with the stone impacted behind it might become obliterated just as the orifice of a common sacculus of the bladder in which a calculus is lodged may be.

If the ureteral orifice became closed it might be impossible to distinguish on palpating or inspecting the bladder a calculus impacted in the ureter from one enclosed within a sac formed by a pouch of the ureter and propelled between the coats of the bladder. In neither case would an aperture of any kind be seen or felt, and if the sac were laid open there would be found in both cases an epithelial lining on the inner or ureteral, as well as on the outer or vesical, surface ; in either case the outstretched ureteral wall might be so compressed against the lining membrane of the bladder as to make them appear like a single structure. If the ureteral wall had ulcerated before the calculus was propelled beneath the bladder mucous coat the inner wall of the sac would be deficient in an epithelial lining.

No differential diagnosis between the two classes of cases can be made clinically. The presence of nephrectasis ${ }^{4}$ is not characteristic of the one as distinct from the other. If obstruction by an impacted ureteral calculus has been complete from the first the kidney atrophies; if, on the other hand, the obstruction is partial and continuous the kidney may be very little altered; whereas if the obstruction is incomplete with occasional intermissions of complete obstruction renal dilatation with atrophy of the parenchyma is produced. A considerable degree of nephrectasis may exist without giving rise to a swelling which can be detected at the bedside.

It is the same with a calculus in a closed pouch of the ureter and with a calculus in an ordinary vesical sacculus if near the ureteral orifice. Either may cause complete or only partial obstruction throughout, or incomplete obstruction with intermissions of complete obstruction. Suppurative pyelitis is much more likely to occur in "ureteral sac" cases, because urine getting from the ureter into the sac would lead to decomposition and this to ascending ureteritis extending to the kidney. The occasional intermittent discharge of large quantities of pus with the urine has been caused in this way.

From cystitis.-In so many cases of renal and ureteral calculus the leading symptoms, and very frequently the only symptoms, have reference to the bladder; consequently the patients are often treated for cystitis. This deplorable error would not so often be made if more attention were given to the examination of the urine and especially to its effect upon litmus paper. With calculus in the kidney or ureter the urine is more or less acid; even when it contain a large quantity of blood or pus it is, as a rule, still slightly acid. The pyuria of pyelitis or pyelonephritis produces a uniform turbidity, and the turbidity continues even after the urine has had time to deposit, showing that much pus remains diffused throughout its volume; moreover, there is an absence of any marked quantity of mucus. With cystitis the degree of pyuria also varies extremely, but the pus is most abundant at the beginning and ending of micturition, indicating that its source is the mucons membrane of the bladder. The urine is akaline, deposits a large quantity of stringy mucus, is offensive, and has often a strong ammoniacal odour when, or soon after, it is voided.

4 I have suggested and have used this term to embrace every form of distension of the renal cavity, whether with urine, pus, or blood. It therefore embraces hydronephrosis, pyonephrosis, and hæmatonephrosis.
A calculus impacted at the vesical orifice of the ureter, especially if it projects into the bladder, may give rise to cystitis; but in this case sounding the bladder, digital examination by the rectum or the vagina of the lower end of the ureter, and bimanual examination of the empty bladder under an anæsthetic will enable the surgeon to make out the presence and situation of the impacted stone. In several of the cases in my list the calculus has been felt by vaginal examination.

From ureteritis. - When the irritation caused by calculus in the ureter is chronic, inflammation of the ureteral walls is likely to supervene There is nothing which distinguishes calculous ureteritis from other forms of inflammation of the ureter except the tuberculous. The mode of onset, the history of renal colic, and possibly the former passing of calculi indicate stone but are not absolutely characteristic. A ureter involved in its whole length either by tuberculous or simple inflammation usually has its tenderest point to pressure at the brim of the bony pelvis, and if there is here a considerable induration of the peri-ureteral tissue as there often is in chronic ureteritis from any cause, it may form a nodule or lump which is very liable to be mistaken for a calculus. In tuberculous ureteritis tubercle bacilli may be found in the urine.

From the early stage of vesical tuberculosis.-The urine in vesical tuberculosis before the disease has reached the stage of tuberculous cystitis is clear and pale except when tinged with blood. With increased frequency of micturition there is often increase in the quantity of urine which may amount to three or four pints in 24 hours. Tubercle bacilli will most likely be discovered in this clear urine by the microscope and by cultivation experiments. When cystitis supervenes the urine will contain pus and mucus. The pus may be flocculent and slight in amount and be contained chiefly in the urine first passed, not uniformly diffused throughout the whole quantity of urine, as it is when derived from the ureter and renal pelvis. The tubercle bacilli are not often found in purulent urine. The bæmaturia of tuberculosis is at first so slight as to escape notice or it makes the urine faintly pink or rose-tinted throughout, though there may be a few drops of pure blood at the end of micturition. It is spontaneous, coming and going withont obvious cause. Hæmaturia and pain are sometimes increased by movement and standing but are not relieved by rest and the horizontal posture, as the bæmaturia and pain caused by calculus gene. rally are; indeed, in tuberculosis the symptoms are often aggravated at night and by the recumbent position.

From prolapsed and adherent ovary.-There are at least two instances on record where a calculus impacted in the lower end of the ureter has been mistaken and operated upon for a prolapsed, tender, and adherent ovary. It may be well, therefore, to point out some of the characteristics by which the two conditions may usually be distinguished, and I am indebted to Dr. Cullingworth for his assistance in doing so. A calculus lodged in the terminal portion of the ureter would be felt through the lateral fornix of the vagina or through the antero-lateral vaginal wall below the level of the cervix uteri, as a hard, oblong body, lying sufficiently loosely in the cellular tissue to have a fair amount of mobility and with its long axis corresponding with the direction of the ureter. A prolapsed and adherent ovary, on the other hand, would be situated within the peritoneal cavity, either in Douglas's pouch (where the question of its being a calculus in the ureter could not arise) or lying on the floor of the fossa behind one of the broad ligaments. In the latter case it would have a greater thickness of tissue between it and the examining finger than would a calculus in the ureter. Moreover, an ovary would never be found on the outer side of the antero-lateral wall of the vagina or anywhere below or in front of the cervix uteri. Other differential characters would be found in the greater hardness and distinct mobility of the calculus, in the direction of its long axis, and in the fact of there almost invariably being, in the case of a prolapsed and adherent ovary, other evidences of old pelvic peritonitis. The condition perhaps most in danger of imposing upon the unwary is where an adherent and prolapsed ovary is lying on a hard and thickened pelvic tloor after an attack of severe pelvic peritonitis. The fixed and diffuse character of the hard. ness as contrasted with the well-defined, intensely hard, and strictly localised swelling caused by the presence of a calculus serves, however, clearly to distinguish it. If by any chance a calculus became impacted a little higher in the ureter - that is, before it is crossed by the uterine artery-it would, especially if on the left side, be easily felt through 
Table of 47 Cases of Operation for UReTeral Calculus Classified according to the Nature of the Operation Performad.

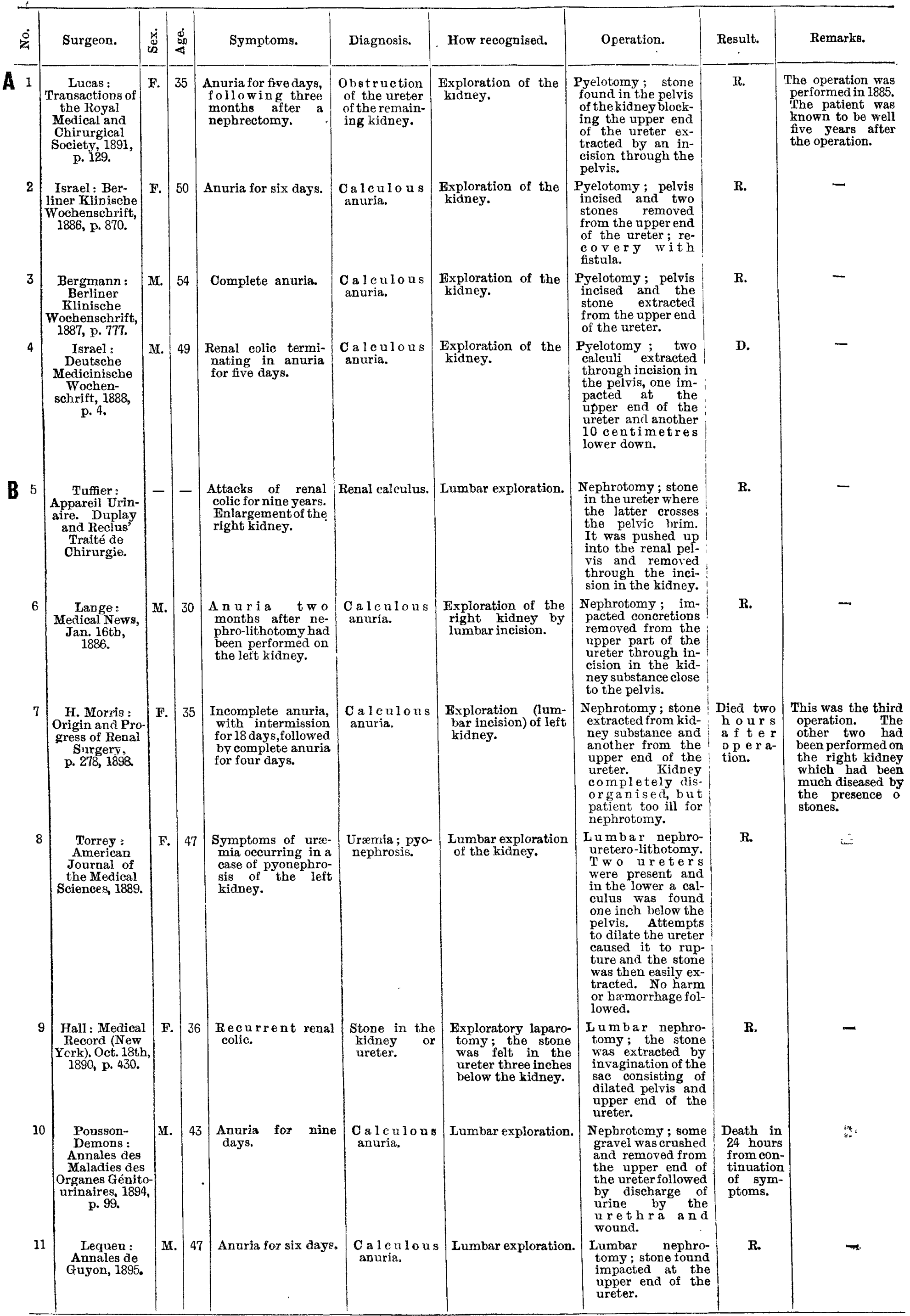


Table of 47 Cases of Operation for UReteral Calculus Classified according to the Natura of the Operation Perhormed-(Continued).

\begin{tabular}{|c|c|c|c|c|c|c|c|c|c|}
\hline$\dot{0}$ & Surgeon. & $\underset{\dot{d}}{\dot{x}}$ & $\dot{8}$ & Symptoms. & Diagnosis. & How recognised. & Operation. & Result. & Remarks. \\
\hline 12 & $\begin{array}{c}\text { Lequeu : } \\
\text { Annales de } \\
\text { Guyon, } 1895 .\end{array}$ & M. & 54 & Anuria for six dajs. & $\begin{array}{l}\text { Oa leulous } \\
\text { anuria. }\end{array}$ & $\begin{array}{l}\text { Left Iumbar ex- } \\
\text { ploration. }\end{array}$ & $\begin{array}{l}\text { Nephrotomy; stone } \\
\text { was taken out of } \\
\text { the upper end of } \\
\text { the ureter through } \\
\text { incision in the } \\
\text { kidney. }\end{array}$ & D. & 一 \\
\hline 13 & $\begin{array}{c}\text { Israel: Presse } \\
\text { Médicale, } \\
\text { April,8th, 1896. }\end{array}$ & F. & 45 & $\begin{array}{l}\text { Attacks of renal } \\
\text { colic for eight years } \\
\text { on both sides, ter- } \\
\text { minating in an } \\
\text { attack of anuria } \\
\text { for six days. }\end{array}$ & $\begin{array}{l}\text { Ca l culous } \\
\text { anuria. }\end{array}$ & $\begin{array}{l}\text { Exploration of the } \\
\text { kidney. }\end{array}$ & $\begin{array}{l}\text { Nephrotomy ; stone } \\
\text { was found in } \\
\text { the ureter two } \\
\text { centimetres below } \\
\text { the innominate } \\
\text { line. In pushing } \\
\text { the stone up the } \\
\text { pelvis tore away } \\
\text { from the kidney. } \\
\text { This was sutured } \\
\text { and a tampon was } \\
\text { put in. }\end{array}$ & $\mathbf{R}$. & $\begin{array}{l}\text { The wound finally } \\
\text { healed com- } \\
\text { pletely. }\end{array}$ \\
\hline 14 & \begin{tabular}{|c|} 
Cotterell : \\
Transactions \\
of the Royal \\
Medical and \\
Ohirurgical \\
Society, Lon- \\
don, vol. Lxxvii.
\end{tabular} & F. & 44 & $\begin{array}{l}\text { Pain after micturi- } \\
\text { tion. }\end{array}$ & $\begin{array}{l}\text { Stone in the } \\
\text { bladder. }\end{array}$ & $\begin{array}{l}\text { Digital exploration } \\
\text { of the bladder } \\
\text { revea led t wo } \\
\text { calculi in the } \\
\text { right ureter. }\end{array}$ & $\begin{array}{l}\text { Vaginal uretero- } \\
\text { tomy; stones re- } \\
\text { moved by incision } \\
\text { through the roof of } \\
\text { the vagina. }\end{array}$ & $\mathbf{R}$. & - \\
\hline 15 & $\begin{array}{c}\text { Doyen } \\
\text { Glantenay: } \\
\text { Chirurgie de } \\
\text { l'Uretère, } \\
\text { p. } 126 .\end{array}$ & F. & 21 & $\begin{array}{l}\text { Vesical pain ; fre- } \\
\text { quency of micturi- } \\
\text { tion. }\end{array}$ & Calculus. & $\begin{array}{l}\text { Stone in the lower } \\
\text { end of the ureter } \\
\text { detected by a } \\
\text { vaginal examina- } \\
\text { tion. }\end{array}$ & $\begin{array}{l}\text { Vaginal uretero- } \\
\text { tomy; ureteral } \\
\text { wound closed by } \\
\text { sutures. }\end{array}$ & R. & - \\
\hline 16 & $\begin{array}{c}\text { Cabot: } \\
\text { Boston } \\
\text { Medical and } \\
\text { Surgical } \\
\text { Journal, Dec. } \\
\text { 25th, 1890. }\end{array}$ & F. & 39 & $\begin{array}{l}\text { Attacks of renal } \\
\text { colic for } 16 \text { years; } \\
\text { often followed by } \\
\text { passage of stones. } \\
\text { Left pyonephrosis } \\
\text { felt as a tumour. }\end{array}$ & Calculus. & $\begin{array}{l}\text { Vaginal examina- } \\
\text { tion revealed a } \\
\text { small hard mass } \\
\text { in the left broad } \\
\text { ligament close to } \\
\text { the cervix uteri. }\end{array}$ & $\begin{array}{l}\text { Vaginal uretero- } \\
\text { tomy; stone re- } \\
\text { moved through the } \\
\text { vagina; } 10 \text { or } 12 \\
\text { ounces of pus were } \\
\text { evacuated ; tumour } \\
\text { of the kidney dis- } \\
\text { appeared. }\end{array}$ & $\mathbf{R}$. & $\begin{array}{l}\text { Ureter o-vaginal } \\
\text { fistula remained } \\
\text { for four months. } \\
\text { The secreting } \\
\text { tissue of the } \\
\text { kidney was } \\
\text { thought to be de- } \\
\text { stroyed. }\end{array}$ \\
\hline 17 & $\begin{array}{c}\text { Th. Addis } \\
\text { Fmmett: } \\
\text { Principles } \\
\text { and Practice } \\
\text { of Gynæcology, } \\
1879 .\end{array}$ & $\mathbf{F}$ & - & - & Calculus. & $\begin{array}{l}\text { Stone in the lower } \\
\text { end of the ureter } \\
\text { detected by the } \\
\text { "click" of a sound } \\
\text { in the bladder. On } \\
\text { backward pressure } \\
\text { with a larger sound } \\
\text { the stone could be } \\
\text { felt through the } \\
\text { vag i n a and } \\
\text { rectum. }\end{array}$ & $\begin{array}{l}\text { Vaginal uretero- } \\
\text { tomy; stone re- } \\
\text { moved by an open- } \\
\text { ing through the } \\
\text { vaginal wall, which } \\
\text { was closed with } \\
\text { int e r r p ted } \\
\text { sutures. }\end{array}$ & $\mathbf{R}$. & 0 \\
\hline 18 & $\begin{array}{l}\text { Ceci, quoted } \\
\text { by Vailhen : } \\
\text { Riforma } \\
\text { Medica, 1887. }\end{array}$ & - & - & Anuria. & Calculus. & Per rectum. & $\begin{array}{l}\text { Ureterot om } \\
\text { through the } \\
\text { rectum; calculus } \\
\text { extracted from the } \\
\text { ureter by an in- } \\
\text { cision through the } \\
\text { rectum. }\end{array}$ & R. & $\rightarrow$ \\
\hline 19 & $\begin{array}{c}\text { Thornton: } \\
\text { Harveian } \\
\text { Tectures, 1889. }\end{array}$ & F. & - & - & 一 & $\longrightarrow$ & $\begin{array}{l}\text { Vesico-uretero- } \\
\text { tomy; stone re- } \\
\text { moved from the } \\
\text { lower end of the } \\
\text { ureter through the } \\
\text { bladder. A ure- } \\
\text { teral fistula re- } \\
\text { sulted and urine } \\
\text { was discharged } \\
\text { into the pouch of } \\
\text { Douglas. }\end{array}$ & D. & - \\
\hline 20 & $\begin{array}{l}\text { Th. Addis } \\
\text { Emmett: } \\
\text { Principles } \\
\text { and Practice } \\
\text { of Gynæeco- } \\
\text { logy, 1879. }\end{array}$ & F. & - & - & 一 & - & $\begin{array}{l}\text { Vesico-uretero- } \\
\text { tomy ; removal of } \\
\text { calculus through } \\
\text { the bladder by } \\
\text { means of curette } \\
\text { forceps, after open- } \\
\text { ing the bladder. }\end{array}$ & - & - \\
\hline 21 & $\begin{array}{c}\text { Briddon : New } \\
\text { York Medical } \\
\text { Journal, 1890, } \\
\text { p. } 582 .\end{array}$ & M. & 15 & $\begin{array}{l}\text { Paroxysms of ab- } \\
\text { dominal pain re- } \\
\text { ferred especially to } \\
\text { the left side; head- } \\
\text { ache, nausea, and } \\
\text { vomiting; albu- } \\
\text { minuria and py- } \\
\text { uria; develop- } \\
\text { ment of an area of } \\
\text { dulness and in- } \\
\text { duration in the left } \\
\text { inguinal region. }\end{array}$ & - & $\begin{array}{l}\text { Incision in the left } \\
\text { groin and evacua- } \\
\text { tion of ten ounces } \\
\text { of pus; wound } \\
\text { found to lead up } \\
\text { to the left kidney; } \\
\text { this wound was } \\
\text { again explored a } \\
\text { week later and it } \\
\text { was then decided } \\
\text { to explore the } \\
\text { kidney. }\end{array}$ & $\begin{array}{l}\text { Lumbar nephrec- } \\
\text { tomy, Oct. 5th; } \\
\text { the kidney sub- } \\
\text { stance contained } \\
\text { multiple abscesses. }\end{array}$ & $\begin{array}{l}\text { Death, } \\
\text { Nov. 23rd. }\end{array}$ & $\begin{array}{l}\text { At the post- } \\
\text { mortem examina- } \\
\text { tion the right } \\
\text { ureter was found } \\
\text { to be double and } \\
\text { one portion con- } \\
\text { tained a calculus, } \\
\text { which extended } \\
\text { down into it from } \\
\text { the pelvis of the } \\
\text { kidney. There } \\
\text { were numerous } \\
\text { abscesses in the } \\
\text { right lung, also } \\
\text { a large amount } \\
\text { of pus over the } \\
\text { anterior balf of } \\
\text { the left hemi- } \\
\text { sphere of the } \\
\text { brain. }\end{array}$ \\
\hline
\end{tabular}


Takle of 47 Cases of Operation for UReterat OAlculus Classified aCcording to the Nature of The Operation Performed-(Continued).

\begin{tabular}{|c|c|c|c|c|c|c|c|c|c|}
\hline$\dot{0}$ & Surgeon. & $\stackrel{\dot{d}}{\dot{\omega}}$ & 离 & Symptoms. & Diagnosis. & How recognised. & Operation. & Result. & Remarks. \\
\hline 2! & $\begin{array}{c}\text { H. Morris } \\
(1890): \\
\text { Hunterian } \\
\text { Lectures, 1898, } \\
\text { p. 184. }\end{array}$ & M. & 38 & $\begin{array}{l}\text { Pain for six years ; } \\
\text { previous passage of } \\
\text { calculi frequent } \\
\text { micturition ; py- } \\
\text { uria; pain in both } \\
\text { loins, chiefly in } \\
\text { the left. }\end{array}$ & Renal calculus. & $\begin{array}{l}\text { Post }- \text { mor te m } \\
\text { examination. }\end{array}$ & $\begin{array}{l}\text { Nephrectomy ; left } \\
\text { kidney weighed } \\
\text { a little over two } \\
\text { ounces; in state } \\
\text { of chronic nephri- } \\
\text { tis; cysts and cal- } \\
\text { culous débris in } \\
\text { the left kidney } \\
\text { urine freely passed } \\
\text { after operation. }\end{array}$ & $\begin{array}{l}\text { sudden } \\
\text { death } \\
\text { on the } \\
\text { second } \\
\text { day after } \\
\text { opera- } \\
\text { tion. }\end{array}$ & $\begin{array}{l}\text { Calculus in the } \\
\text { left ureter two } \\
\text { inches from the } \\
\text { lower end. The } \\
\text { right kidney was } \\
\text { omall and in a } \\
\text { state of chronic } \\
\text { interstitial in- } \\
\text { flammation. }\end{array}$ \\
\hline 23 & $\begin{array}{l}\text { Richardson : } \\
\text { Boston Medical } \\
\text { and Surgjeal } \\
\text { Journal, } \\
\text { April 13th, } \\
\text { 1893, p. 359. }\end{array}$ & F. & 33 & $\begin{array}{l}\text { Symptoms of dys- } \\
\text { pepsia with occa- } \\
\text { sional vomiting } \\
\text { thepain afterwards } \\
\text { became referred to } \\
\text { the left lumbar } \\
\text { region and a large } \\
\text { fl } u \text { c } t \text { a } t \text { i n g } \\
\text { tumour developed. }\end{array}$ & $\underset{\text { nephrosis. }}{\mathbf{H}} \underset{\mathrm{f}}{\mathbf{d}} \mathbf{\mathbf { r }} \mathbf{0}^{-}$ & $\begin{array}{l}\text { Presence of hydro- } \\
\text { nephrosis on the } \\
\text { left side. }\end{array}$ & $\begin{array}{l}\text { Abdominal nephrec- } \\
\text { to m y d o u ble } \\
\text { ureter; one ureter } \\
\text { blocked by cal- } \\
\text { culus, with hydro- } \\
\text { nephrosis of the } \\
\text { corresponding part } \\
\text { of the kidney, } \\
\text { while the rest of } \\
\text { kidney-i.e., about } \\
\text { a quarter of it- } \\
\text { was normal with } \\
\text { patent ureter. }\end{array}$ & R. & - \\
\hline 24 & $\begin{array}{l}\text { Jordan' Lloy d : } \\
\text { Brit. Med. } \\
\text { Jour., Oet. 24th, } \\
\text { 1896, p. 1208, }\end{array}$ & M. & 37 & $\begin{array}{l}\text { Subject to paroxys- } \\
\text { mal pain in the } \\
\text { leftloin for } 22 \text { years } \\
\text { and had often had } \\
\text { hæmaturia. The } \\
\text { urine contained a } \\
\text { trace of blood, but } \\
\text { no crystals. Py- } \\
\text { uria. During the } \\
\text { period of pain less } \\
\text { urine was passed, } \\
\text { with scarcely a } \\
\text { trace of pus. }\end{array}$ & $\begin{array}{l}\text { Symptoms } \\
\text { simulated } \\
\text { renal cal- } \\
\text { culus. }\end{array}$ & $\begin{array}{l}\text { Post-mortem } \\
\text { examination. }\end{array}$ & $\begin{array}{l}\text { Lumbar nephreo- } \\
\text { tomy. The kid- } \\
\text { ney was small, } \\
\text { s hrivelled, and } \\
\text { tough. Obviously } \\
\text { it was useless and } \\
\text { it was therefore re- } \\
\text { moved. }\end{array}$ & $\begin{array}{l}\text { Death } 64 \\
\text { h o u r s } \\
\text { after ope- } \\
\text { ration. }\end{array}$ & 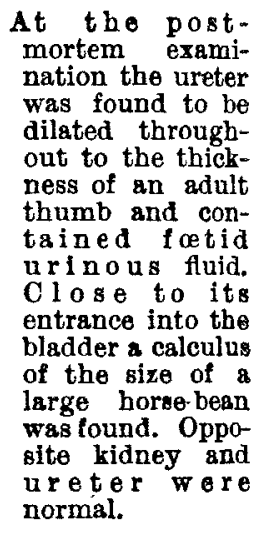 \\
\hline 25 & $\begin{array}{c}\text { Bardenhener, } \\
\text { quoted by } \\
\text { Thelen: } \\
\text { Centralblat } \\
\text { für Chirurgite, } \\
\text { Mareh 25th } \\
\text { 1882. }\end{array}$ & F. & 27 & $\begin{array}{l}\text { Complete anuria for } \\
\text { two days. }\end{array}$ & $\begin{array}{l}\text { Calculous } \\
\text { anuria. }\end{array}$ & $\begin{array}{l}\text { Lumbar exploration } \\
\text { of the right kidney. }\end{array}$ & $\begin{array}{l}\text { Uretero - lithotomy } \\
\text { (extra - peritoneal). } \\
\text { Calculus extracted } \\
\text { from the upper end } \\
\text { of the ureter. The } \\
\text { incised ureter was } \\
\text { fixed to the wound, } \\
\text { thus making a } \\
\text { permanent fistula. }\end{array}$ & $\mathbf{R}$. & $\begin{array}{l}\text { The left kidney } \\
\text { was destroyed } \\
\text { by suppuration } \\
\text { consequent upon } \\
\text { cystitis. }\end{array}$ \\
\hline 26 & $\begin{array}{c}\text { Ralfe and } \\
\text { Godlee: } \\
\text { Brit. Med. } \\
\text { Jour., 1889 } \\
\text { p. } 474 .\end{array}$ & F. & 26 & $\begin{array}{l}\text { Attacks of renal } \\
\text { colic on the left } \\
\text { side; anuria for } 53 \\
\text { hours. }\end{array}$ & $\begin{array}{l}\text { Caleulous } \\
\text { anuria. }\end{array}$ & $\begin{array}{l}\text { Lumbar explora- } \\
\text { tion. }\end{array}$ & $\begin{array}{l}\text { Uretero - lithotomy } \\
\text { (extra-peritoneal); } \\
\text { stone blocking the } \\
\text { ureter two inches } \\
\text { below the kidney } \\
\text { long i t ud in a } \\
\text { uretero-lithotomy. }\end{array}$ & $\mathbf{R}$. & - \\
\hline 27 & $\begin{array}{l}\text { Xirkham: } \\
\text { TrE LANCET, } \\
\text { March 16th, } \\
\text { 1889, p. } 526 .\end{array}$ & M. & 58 & $\begin{array}{l}\text { Attaciss of left renal } \\
\text { colic followed by } \\
\text { anuria for five } \\
\text { days; previously } \\
\text { there had been } \\
\text { renal colic on the } \\
\text { right side. }\end{array}$ & $\begin{array}{l}\text { Destruction of } \\
\text { right kidney } \\
\text { by previous } \\
\text { at a c k s } \\
\text { a n u r i a } \\
\text { caused by } \\
\text { disease of } \\
\text { left kidney. }\end{array}$ & $\begin{array}{l}\text { Left lumbar in- } \\
\text { cision. }\end{array}$ & $\begin{array}{l}\text { Calculus felt balf } \\
\text { an inch above } \\
\text { where ureter } \\
\text { crosses the ex- } \\
\text { ternal iliac artery; } \\
\text { retro-peritoneal } \\
\text { uretero-lithotomy } \\
\text { by extension of the } \\
\text { lumbar incision; } \\
\text { removal of stone; } \\
\text { no sutures. }\end{array}$ & R. & - \\
\hline 28 & $\begin{array}{c}\text { Twynam: } \\
\text { Transactions } \\
\text { of the Clinieal } \\
\text { Society of } \\
\text { London, } \\
\text { vol. xxiii., } \\
\text { 1890. }\end{array}$ & $\mathrm{M}$. & 8 & $\begin{array}{l}\text { Renal pain on the } \\
\text { left side; hæma- } \\
\text { turia. }\end{array}$ & - & $\begin{array}{l}\text { Fxploratory laparo- } \\
\text { tomy showed stone } \\
\text { in the right ureter } \\
\text { just below brim of } \\
\text { the pelvis. }\end{array}$ & $\begin{array}{l}\text { Uretero - lithotomy } \\
\text { (extra - peritoneal) } \\
\text { in right iliacregion } \\
\text { three weeks after } \\
\text { the exploratory } \\
\text { laparotomy. btone } \\
\text { wa s m o v ; } \\
\text { wound in ureter } \\
\text { sutured ; drain- } \\
\text { tube inserted into } \\
\text { retro-peritoneal } \\
\text { space. }\end{array}$ & $\mathbf{R}$. & $\cdot \vdots$ \\
\hline 29 & $\begin{array}{c}\text { Cabot: } \\
\text { American } \\
\text { Journal of } \\
\text { the Medical } \\
\text { Sciences, } \\
\text { January, Iz9, } \\
\text { p. } 4 \mathrm{i}\end{array}$ & M. & 40 & $\begin{array}{l}\text { Sharp attacks of } \\
\text { pain referred to } \\
\text { the left side of the } \\
\text { abdomen above the } \\
\text { middle of Pou- } \\
\text { part's ligament. } \\
\text { During three } \\
\text { month before } \\
\text { operation there } \\
\text { was a sensitive spot } \\
\text { in the back midway } \\
\text { between the crest of } \\
\text { the ilium and the } \\
\text { twelfth rib. }\end{array}$ & $\begin{array}{l}\text { Stone in the } \\
\text { ureter di a- } \\
\text { gnosed. }\end{array}$ & Tumbar incision. & $\begin{array}{l}\text { Uretero - lithotomy } \\
\text { (extra-peritoneal). } \\
\text { Removal of cal- } \\
\text { culus from the } \\
\text { ureter two inches } \\
\text { below the kidney. } \\
\text { The wound in the } \\
\text { ureter wa not } \\
\text { uutured. }\end{array}$ & $\mathbf{R}$. & - \\
\hline
\end{tabular}


Table of 47 Cases of Operation for Ureteral Calculus Classified according to the Nature of the Operation Performed-(Continued).

\begin{tabular}{|c|c|c|c|c|c|c|c|c|c|}
\hline 宫 & Surgeon. & $\stackrel{\not ்}{\mathscr{D}}$ & $\dot{8}$ & Symptoms. & Disgnosis. & How recognised. & Operation. & Result. & Remarks. :- \\
\hline 30 & $\begin{array}{c}\text { Fenger: } \\
\text { Chicago } \\
\text { Medical } \\
\text { Record, } \\
\text { March, } 1893 .\end{array}$ & $M$. & 35 & $\begin{array}{l}\text { Increasing attacks } \\
\text { of renal colic for } \\
\text { two years; no } \\
\text { hæmaturia; no } \\
\text { tumour. }\end{array}$ & $\underset{\text { lithiasis. }}{\text { Nephro- }}$ & $\begin{array}{l}\text { Lumbar incision; } \\
\text { palpation revealed } \\
\text { two stones in the } \\
\text { ureter one and a } \\
\text { half inches below } \\
\text { the kidney. }\end{array}$ & $\begin{array}{l}\text { Uretero - lithotomy } \\
\text { (extra-peritoneal). } \\
\text { longitudinal in- } \\
\text { cision in the ureter } \\
\text { and removal of } \\
\text { stones. No sutures } \\
\text { were used. }\end{array}$ & $\mathbf{R}$. & - \\
\hline 31 & $\begin{array}{l}\text { Hind: } \\
\text { Brit. Med. } \\
\text { Jour., } \\
\text { vol. i., } 1894 . \\
\text { p. } 960 .\end{array}$ & M. & 55 & $\begin{array}{l}\text { Suppression of } \\
\text { urine for } 6 \text { days. }\end{array}$ & Renal calculus. & $\begin{array}{c}\text { Exploration of the } \\
\text { right kidney. }\end{array}$ & $\begin{array}{l}\text { Uretero - lithotomy } \\
\text { and nephro-lith- } \\
\text { otomy (extra-peri- } \\
\text { toneal). Calculus } \\
\text { was found block- } \\
\text { ing the upper end } \\
\text { of the ureter; } \\
\text { several s mall } \\
\text { stones in pelvis } \\
\text { werealso extracted } \\
\text { through the same } \\
\text { incision in the } \\
\text { ureter. } \\
\text { stone (36 grains) } \\
\text { was also removed } \\
\text { from the kidney } \\
\text { substance. }\end{array}$ & $\begin{array}{l}\text { Death } 58 \\
\text { h o u r s } \\
\text { a f t e r } \\
\text { opera- } \\
\text { tion. }\end{array}$ & $\begin{array}{l}\text { After the operation } \\
\text { urine was freely } \\
\text { passed till death. } \\
\text { The left kidney } \\
\text { proved to be a } \\
\text { mere shell, due to } \\
\text { previous similar } \\
\text { disease. }\end{array}$ \\
\hline 32 & $\begin{array}{c}\text { Unpublished. } \\
\text { Quoted by H. } \\
\text { Morris : } \\
\text { Origin and } \\
\text { Progress of } \\
\text { Rena1 Sur- } \\
\text { gery, p. } 77 .\end{array}$ & $\mathbf{M}$. & 32 & $\begin{array}{l}\text { After pain in the } \\
\text { right loin for two } \\
\text { months had an } \\
\text { attack of right } \\
\text { renal colic. Sub- } \\
\text { sequently pain in } \\
\text { the right loin, } \\
\text { always brought on } \\
\text { by exertion. A } \\
\text { second violent } \\
\text { attack of colic with } \\
\text { pain in the line of } \\
\text { the ureter where it } \\
\text { crosses the pelvic } \\
\text { brim and a hard } \\
\text { body like a stone } \\
\text { could be felt there } \\
\text { through the ab- } \\
\text { dominal wall. }\end{array}$ & $\begin{array}{c}\text { Stone } \\
\text { ureter. }\end{array}$ in & $\begin{array}{l}\text { Felt through the } \\
\text { abdominal wall at } \\
\text { the pelvic brim. }\end{array}$ & $\begin{array}{l}\text { Exploratory colio- } \\
\text { tomy in the } \\
\text { median line and } \\
\text { through this in- } \\
\text { cision the small } \\
\text { rough stone in the } \\
\text { ureter was ascer- } \\
\text { tained to be pre- } \\
\text { sent. Retro-peri- } \\
\text { toneal ureterotomy } \\
\text { was performed } \\
\text { through a slightly } \\
\text { oblique wound in } \\
\text { the il i o-cos tal } \\
\text { space. The calculus } \\
\text { was steadied by the } \\
\text { hand of an assist- } \\
\text { ant passed through } \\
\text { the abdominal in- } \\
\text { cision. }\end{array}$ & R. & $\begin{array}{l}\text { The walls of the } \\
\text { ureter did not } \\
\text { heal satisfactorily } \\
\text { and extravasation } \\
\text { of urine took } \\
\text { place. }\end{array}$ \\
\hline 33 & $\begin{array}{l}\text { Jordan Lloyd : } \\
\text { Brit. Med. } \\
\text { Jour., } \\
\text { Oct.24th, 1896, } \\
\text { p. 1207. } \\
\end{array}$ & $F$. & 35 & $\begin{array}{l}\text { Attacks of left renal } \\
\text { colic of two years } \\
\text { duration occurring } \\
\text { every four or five } \\
\text { w ee s. Sli ght } \\
\text { hematuria and } \\
\text { some oxalate crys- } \\
\text { tals in the urine. }\end{array}$ & $\begin{array}{l}\text { Symptoms } \\
\text { pointed to } \\
\text { renal calcu- } \\
\text { lus. }\end{array}$ & $\begin{array}{l}\text { Exploration of the } \\
\text { left kidney with } \\
\text { negative result. } \\
\text { Stoue was found } \\
\text { by an intra-peri- } \\
\text { toneal incision, } \\
\text { parallel to and one } \\
\text { inch above the } \\
\text { outer third of } \\
\text { Poupart's liga- } \\
\text { ment, to be situ- } \\
\text { ated in the ureter } \\
\text { one inch above its } \\
\text { entrance into the } \\
\text { bladder. }\end{array}$ & $\begin{array}{l}\text { Extra - peritoneal } \\
\text { uretero-lithotomy; } \\
\text { the stone was re- } \\
\text { moved by pro- } \\
\text { longation of the } \\
\text { outer end of the } \\
\text { iliac incision up- } \\
\text { wards and out- } \\
\text { wards as though } \\
\text { for tying the com- } \\
\text { mon iliac artery, } \\
\text { the uncut part of } \\
\text { the peritoneum } \\
\text { being stripped off } \\
\text { from the iliac } \\
\text { fossa. }\end{array}$ & B. & $\begin{array}{l}\text { The ureter was not } \\
\text { sutured, there } \\
\text { was no escape of } \\
\text { urine, and a per- } \\
\text { fect recovery took } \\
\text { place. }\end{array}$ \\
\hline 34 & $\begin{array}{c}\text { Israel : } \\
\text { Presse Médl- } \\
\text { cale, } \\
\text { April 8th, } 1896 .\end{array}$ & Mr. & - & $\begin{array}{c}\text { Anuria for six } \\
\text { days. }\end{array}$ & $\begin{array}{l}\text { Calculous } \\
\text { anuria. }\end{array}$ & $\begin{array}{l}\text { Exploration of } \\
\text { the kidney. }\end{array}$ & $\begin{array}{l}\text { Nephrotomy; ure- } \\
\text { tero-lithotomy (ex- } \\
\text { tra-perito e al); } \\
\text { stones were found } \\
\text { in the kidney and } \\
\text { one two centi- } \\
\text { metres below the } \\
\text { commencement of } \\
\text { the ureter. Re- } \\
\text { moved through an } \\
\text { incision in the } \\
\text { ureter. }\end{array}$ & $\boldsymbol{R}$. & $\begin{array}{l}\text { In this case the } \\
\text { kidney operated } \\
\text { upon was the only } \\
\text { one the patient } \\
\text { possessed. }\end{array}$ \\
\hline 35 & $\begin{array}{l}\text { H. B. Robin- } \\
\text { son : } \\
\text { Brit. Med. } \\
\text { Jour., } \\
\text { vol. ii., } 1897 \text {, } \\
\text { p. } 648 . \\
\end{array}$ & F. & 23 & $\begin{array}{l}\text { Attacks of renal } \\
\text { colic sines the age } \\
\text { of } 15 \text { years; ocea- } \\
\text { sional bæmaturia; } \\
\text { right byd ro- } \\
\text { nephrosis. }\end{array}$ & $\begin{array}{l}\text { Thought pro- } \\
\text { bable that } \\
\text { there was an } \\
\text { obs truction } \\
\text { of the ureter. }\end{array}$ & $\begin{array}{l}\text { Urethra dilated and } \\
\text { ureters catheter- } \\
\text { ised. An obstrue- } \\
\text { tion was found in } \\
\text { the right one a } \\
\text { quarter of an inch } \\
\text { trom its termina- } \\
\text { tion. Bimanual ex- } \\
\text { amination showed } \\
\text { this obstruction to } \\
\text { be a body the shape } \\
\text { of a date stone, but } \\
\text { larger, and it was } \\
\text { in relation with the } \\
\text { posterior part of } \\
\text { the cervix uteri. }\end{array}$ & $\begin{array}{l}\text { Uretero-lithotomy } \\
\text { (extra-peritoneal) } \\
\text { incision three and } \\
\text { a half inches long } \\
\text { commencing on a } \\
\text { level with, and } \\
\text { about one inch in- } \\
\text { ternal to, the ante- } \\
\text { rior superior spine } \\
\text { and directed up- } \\
\text { wards and a little } \\
\text { inwards. The peri- } \\
\text { t o n u m w a } \\
\text { stripped of and } \\
\text { the ureter exposed. } \\
\text { The stone was re- } \\
\text { moved through an } \\
\text { incision one inch } \\
\text { in length which } \\
\text { was sutured with } \\
\text { fine interrupted } \\
\text { silk sutures. }\end{array}$ & R. & - \\
\hline
\end{tabular}


Table of 47 Cases of Operation for Ureteral Calculus Classified acconding to the Nature of the Operation Perhormed-(Continued).

\begin{tabular}{|c|c|c|c|c|c|c|c|c|c|}
\hline 完 & Surgeon. & $\begin{array}{l}\dot{Q} \\
\dot{\omega} \\
\dot{n}\end{array}$ & $\stackrel{\dot{\infty}}{\infty}$ & Symptoms. & Diagnosis. & How recognised. & Operation. & Result. & Remarks. \\
\hline 36 & $\begin{array}{c}\text { H. B. Robin- } \\
\text { son : } \\
\text { Transactions } \\
\text { of the Clinical } \\
\text { Society of } \\
\text { London, } 1898 .\end{array}$ & F. & 16 & $\begin{array}{l}\text { Attacks of renal } \\
\text { colie for } 10 \text { years } \\
\text { which gradually } \\
\text { became more fre- } \\
\text { quent. Hydro- } \\
\text { nephrosis on the } \\
\text { left side. }\end{array}$ & $\begin{array}{c}\text { Calculus in } \\
\text { the ureter. }\end{array}$ & $\begin{array}{l}\text { Vaginal examina- } \\
\text { tion detected a } \\
\text { hard body in the } \\
\text { left ureter which } \\
\text { was thought to be } \\
\text { a calculus. }\end{array}$ & $\begin{array}{l}\text { Uretero - lithotomy } \\
\text { (extra-peritoneal); } \\
\text { curved incision } \\
\text { above the internal } \\
\text { abdominal ring ; } \\
\text { p e r i t o n e u } \\
\text { stripped of ves- } \\
\text { sels, Incision of } \\
\text { one inch into the } \\
\text { ureter and oxalate } \\
\text { of limestone (25 } \\
\text { grains) extracted. }\end{array}$ & R. & - \\
\hline 37 & $\begin{array}{l}\text { H. Morris: } \\
\text { June 12th, } \\
\text { 1899. }\end{array}$ & F. & 33 & $\begin{array}{l}\text { After voyage patient } \\
\text { was taken with } \\
\text { pain below the last } \\
\text { rib on the right } \\
\text { side both in the loin } \\
\text { and towards the } \\
\text { front of the abdo- } \\
\text { men, attended by } \\
\text { hæmaturia. Dis- } \\
\text { comfort in the } \\
\text { right renal region } \\
\text { with attacks of } \\
\text { pain and hæma- } \\
\text { turia at increas- } \\
\text { ingly frequent in- } \\
\text { tervals till June, } \\
\text { l899. Pain and } \\
\text { hamorrhage were } \\
\text { increased by the } \\
\text { slightest exercise. }\end{array}$ & $\begin{array}{l}\text { Calculus in } \\
\text { kidney or } \\
\text { upper end of } \\
\text { ureter. }\end{array}$ & $\begin{array}{l}\text { Lumbar incision ; } \\
\text { kidney deeply con- } \\
\text { gested. }\end{array}$ & $\begin{array}{l}\text { Uretero-lithotomy } \\
\text { (extra-peritoneal); } \\
\text { bidney incised } \\
\text { through the con- } \\
\text { vex border; the } \\
\text { lower calyces were } \\
\text { pouched no stone. } \\
\text { The renal pelvis } \\
\text { was somewhat dis- } \\
\text { tended; no stone. } \\
\text { Two inches below } \\
\text { the hilum the } \\
\text { ureter was com- } \\
\text { pletely blocked by } \\
\text { a rough calcium } \\
\text { oxalate stone, the } \\
\text { inequalities of } \\
\text { which were stick- } \\
\text { ing into the walls } \\
\text { of the ureter. } \\
\text { Calculus removed } \\
\text { through longitu- } \\
\text { dinal incision in } \\
\text { the ureter; one } \\
\text { suture. }\end{array}$ & R. & 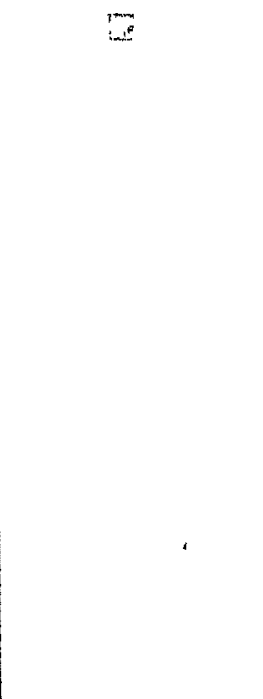 \\
\hline 38 & $\begin{array}{c}\text { Thornton: } \\
\text { Harveian } \\
\text { Oration. }\end{array}$ & F. & - & - & - & $\begin{array}{l}\text { During an abdo- } \\
\text { minal operation } \\
\text { for nephrectomy a } \\
\text { stone was found } \\
\text { half way down the } \\
\text { ureter of the oppo- } \\
\text { site side. }\end{array}$ & $\begin{array}{l}\text { Uretero - lithotomy } \\
\text { (extra-peritoneal); } \\
\text { stone was removed } \\
\text { from the ureter by } \\
\text { a lumbar incision. }\end{array}$ & D. & $\begin{array}{l}\text { Death on the sixth } \\
\text { day from broncho- } \\
\text { pneumonia. }\end{array}$ \\
\hline 39 & $\begin{array}{l}\text { Cotterell : } \\
\text { Transactions } \\
\text { of the Royal } \\
\text { Medical and } \\
\text { Chirurgical } \\
\text { Society, } \\
\text { vol. Ixxvii. }\end{array}$ & F. & 61 & $\begin{array}{l}\text { Symptoms of stone } \\
\text { in the pelvis of the } \\
\text { right kidney ; per- } \\
\text { sistence of pain } \\
\text { and tend erness } \\
\text { after two opera- } \\
\text { tions on the kid- } \\
\text { ney, in the first } \\
\text { of which stones } \\
\text { had been removed. }\end{array}$ & - & - & $\begin{array}{l}\text { Uretero-lithotomy } \\
\text { (extra-peritcneal); } \\
\text { incision as for } \\
\text { tying the common } \\
\text { iliac artery. The } \\
\text { stone was found } \\
\text { just above the true } \\
\text { brim of the pelvis } \\
\text { and extracted } \\
\text { through a small } \\
\text { longitudinal in- } \\
\text { cision. }\end{array}$ & $\mathbf{R}$ & $-m$ \\
\hline 40 & $\begin{array}{c}\text { H. Morris: } \\
\text { Origin and Pro- } \\
\text { gress of Renal } \\
\text { Surgery, 1898. } \\
\text { Table II., } \\
\text { No. 44. }\end{array}$ & M. & 31 & $\begin{array}{l}\text { For seren years } \\
\text { at intervals pain } \\
\text { and bamaturia. } \\
\text { A small stone was } \\
\text { passed in } 1891 \text { and } \\
\text { another in } 1897 .\end{array}$ & Renal caleulus. & $\begin{array}{l}\text { Lumbar explora- } \\
\text { tion, December, } \\
\text { 189?. }\end{array}$ & $\begin{array}{l}\text { Pyelotomy and ex- } \\
\text { traction of a stone } \\
\text { from the renal } \\
\text { pelvis. Uretero- } \\
\text { lithotomy and ex- } \\
\text { traction of a second } \\
\text { stone through an } \\
\text { incision in the } \\
\text { ureter four inches } \\
\text { below the renal } \\
\text { pelvis. }\end{array}$ & R. & 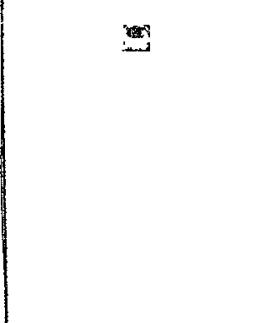 \\
\hline 41 & $\begin{array}{c}\text { Bruce Clarke: } \\
\text { Transactions } \\
\text { of the Medical } \\
\text { Society of } \\
\text { London, } \\
\text { vol. xxil., } \\
\text { p. 104.. }\end{array}$ & F. & - & $\begin{array}{l}\text { Symptoms for two } \\
\text { years attributed to } \\
\text { renal calculus. }\end{array}$ & Renal calculus. & $\begin{array}{l}\text { Lumbar exploration } \\
\text { of kidney. }\end{array}$ & $\begin{array}{l}\text { Lumbar incision } \\
\text { prolonged ; ureter } \\
\text { incised and calcu- } \\
\text { lus extracted from } \\
\text { it at a point five } \\
\text { inches below the } \\
\text { kidney. }\end{array}$ & R. & س \\
\hline 42 & $\begin{array}{c}\text { Freyer: } \\
\text { Transactions } \\
\text { of the Medical } \\
\text { Society of } \\
\text { London, } \\
\text { vol. xxii., } \\
\text { p. } 99 .\end{array}$ & M. & 23 & $\begin{array}{l}\text { Renal colic with } \\
\text { hamaturia for } 19 \\
\text { months. }\end{array}$ & $\begin{array}{l}\text { Renal calcu- } \\
\text { lus } \\
\text { renal with } \\
\text { struetion. }\end{array}$ & $\begin{array}{l}\text { K } \times \text { i o r a t i o n } \\
\text { through an oblique } \\
\text { lumbar incision. } \\
\text { Stone felt in the } \\
\text { ureter four inches } \\
\text { below the kidney. }\end{array}$ & $\begin{array}{l}\text { Loin incision pro- } \\
\text { longed ; ureter in- } \\
\text { cised longitudi- } \\
\text { nally and the cal- } \\
\text { culus removed in } \\
\text { situ. }\end{array}$ & $\mathbf{R}$. & Sis \\
\hline
\end{tabular}


Table of 47 Cases of Operation for UReteral Calculus Classified according to the Natedre of The Operation Performed-(Continued).

\begin{tabular}{|c|c|c|c|c|c|c|c|c|c|}
\hline$\stackrel{\circ}{\circ}$ & Surgeon. & $\stackrel{\dot{x}}{\dot{D}}$ & $\underset{\dot{a}}{\dot{a r}}$ & Symptoms. & Diagnosis. & How recognised. & Operation. & Result. & Remarks. \\
\hline 43 & $\begin{array}{l}\text { Cullingworth : } \\
\text { Transactions } \\
\text { of the Patho- } \\
\text { logical Society } \\
\text { of London, } \\
\text { vol. xxxvi., } \\
\text { p. } 278\end{array}$ & F. & 30 & $\begin{array}{l}\text { Renal colic on the } \\
\text { right side. }\end{array}$ & $\begin{array}{c}\text { Right pyo- } \\
\text { nephrosis } \\
\text { and inde- } \\
\text { penden t } \\
\text { ovarian } \\
\text { disease. }\end{array}$ & $\begin{array}{l}\text { Vaginal examina- } \\
\text { tion showed hard } \\
\text { masses to the right } \\
\text { and left of the } \\
\text { uterus. Laparo- } \\
\text { tomy showed stone } \\
\text { in the right ureter } \\
\text { just above the } \\
\text { bladder. }\end{array}$ & $\begin{array}{l}\text { Ureterotomy (intra- } \\
\text { perit on eal); re- } \\
\text { moval of stone; } \\
\text { escape of pus; in- } \\
\text { terrupted silk } \\
\text { sutures closed the } \\
\text { wound in the } \\
\text { ureter. }\end{array}$ & D. & $\begin{array}{l}\text { Post-mortem exa- } \\
\text { mination showed } \\
\text { double pyo- } \\
\text { nep h ro s i s. } \\
\text { Sutures in the } \\
\text { ureter were } \\
\text { secure. }\end{array}$ \\
\hline 44 & $\begin{array}{c}\text { Lane: } \\
\text { THE LANCET, } \\
\text { Nov. 8th, } \\
\text { 1890, p. } 967 .\end{array}$ & F. & 23 & $\begin{array}{l}\text { Left renal eolic for } \\
20 \text { years ; hæma- } \\
\text { turia; pyuria. }\end{array}$ & Renal calculus. & $\begin{array}{l}\text { Laparotomy showed } \\
\text { pelvis of the left } \\
\text { kidney dilated ; no } \\
\text { stone found. Eight } \\
\text { months later a } \\
\text { second laparotomy } \\
\text { revealed stone. }\end{array}$ & $\begin{array}{c}\text { Ureterotomy (intra- } \\
\text { peritoneal); stone } \\
\text { found in the pelvic } \\
\text { portion of the } \\
\text { ureter and removed } \\
\text { by ureterotomy. } \\
\text { Wound in ureter } \\
\text { closed with con- } \\
\text { tinuous silk suture. }\end{array}$ & $R$. & $\longrightarrow$ \\
\hline 45 & $\begin{array}{c}\text { Roberts: } \\
\text { Annals of Sur- } \\
\text { gery, 1895, } \\
\text { vol. xxii., } \\
\text { p. } 363^{\prime}\end{array}$ & F. & 57 & $\begin{array}{l}\text { Attacks of renal } \\
\text { colic since the age } \\
\text { of } 11 \text { years. Stones } \\
\text { passed on a number } \\
\text { of o c c a s i o s. } \\
\text { Recent attacks of } \\
\text { pain every week } \\
\text { followed by pyuria. }\end{array}$ & $\begin{array}{l}\text { Kenal calcn- } \\
\text { lus thought } \\
\text { probable. }\end{array}$ & 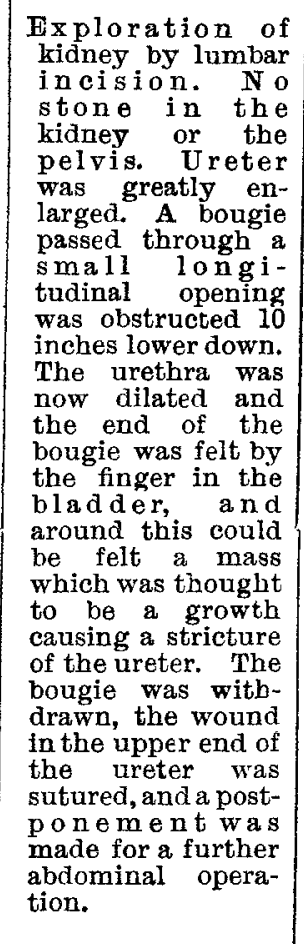 & $\begin{array}{c}\text { Laparotomy; small } \\
\text { stone was found in } \\
\text { the ureter and } \\
\text { removed by trans- } \\
\text { peritoneal method; } \\
\text { ureter was closed } \\
\text { with silk sutures. }\end{array}$ & R. & - \\
\hline 46 & $\begin{array}{l}\text { Roberts: } \\
\text { Referred to } \\
\text { by Perkins }\end{array}$ & F. & - & $\begin{array}{l}\text { A swelling could be } \\
\text { felt through the } \\
\text { vagina behind and } \\
\text { to the left of the } \\
\text { uterus. }\end{array}$ & $\rightarrow$ & $\begin{array}{l}\text { Primary lumbar in- } \\
\text { cision to explore } \\
\text { kidney ; catheteri- } \\
\text { sation showed an } \\
\text { obstruction one } \\
\text { aud a half inches } \\
\text { above the bladder. }\end{array}$ & $\begin{array}{l}\text { Uretero - lithotomy } \\
\text { (intra-peritoneal); } \\
\text { laparotomy per- } \\
\text { formed and stone } \\
\text { removed. }\end{array}$ & - & - \\
\hline 47 & $\begin{array}{c}\text { H. Morris: } \\
\text { American } \\
\text { Journal of the } \\
\text { Medical } \\
\text { Sciences, } \\
\text { October, 1889. }\end{array}$ & F. & 55 & $\begin{array}{l}\text { Gradual onset of } \\
\text { anuria for six } \\
\text { months, whieh was } \\
\text { complete six days } \\
\text { before death. }\end{array}$ & $\begin{array}{c}\text { Stone in lower } \\
\text { end of ureter. }\end{array}$ & $\begin{array}{l}\text { Calculus detected } \\
\text { at the lower end } \\
\text { of the ureter by } \\
\text { means of digital } \\
\text { exploration of the } \\
\text { bladder. }\end{array}$ & $\begin{array}{l}\text { An attempt to dis- } \\
\text { lodge the stone } \\
\text { with the finger } \\
\text { passed through the } \\
\text { urethra into the } \\
\text { bladder failed and } \\
\text { the condition of } \\
\text { the patient did } \\
\text { not allow of any } \\
\text { further operation. }\end{array}$ & D. & $\begin{array}{l}\text { This case has a } \\
\text { conspicuous place } \\
\text { in the history of } \\
\text { uretero-lithotomy } \\
\text { and for that } \\
\text { reason is included } \\
\text { in this table. } \\
\text { Although the } \\
\text { condition of the } \\
\text { patient did not } \\
\text { permit of the ex- } \\
\text { traction of the } \\
\text { calcul u being } \\
\text { completed this } \\
\text { case induced me } \\
\text { to suggest and } \\
\text { publish definite } \\
\text { plans of perform- } \\
\text { ing vesico-uretero- } \\
\text { tomy, and it also } \\
\text { led up to the } \\
\text { development of } \\
\text { other methods of } \\
\text { uret ro-lith o- } \\
\text { tomy. }\end{array}$ \\
\hline
\end{tabular}

H, Uretero-lithotomy (intra-peritoneal).

Besides the cases tabulated here Israel has also referred to three cases of uretero-lithotomy operated upon by himself for impacted stones, two of them by the vaginal method. He also speaks of two cases in which he has removed the ureter entirely filled with stones (Berliner Klinische Wochenschrift, Feb, 27th, 1899). 
the rectum. Its shape, the direction of its long axis, its clearly-defined outline, its relation to the iliac vessels, and its "stony" hardness would again be the chief means of distinguishing it from a displaced and adherent ovary.

\section{Srмpтомs.}

The symptoms are the same as those of renal calculus; and as with a stone in the kidney, so also with one in the ureter, it may be either unsuspected or quiescent, no symptom whatever may cause its presence to be known during life, and its discovery may be a surprise on post-mortem examina. tion; or it may excite symptoms which point to some other part or organ, not to the ureter; or after causing more or less severe disturbance it may settle down and become quiescent for years.

In thin persons when the stone has been impacted just above the brim of the bony pelvis a small hard body has in rare cases been felt through the abdominal wall. If in the presence of the ordinary symptoms of stone in the kidney the position of such a lump corresponds with the seat of a constant pain and of a pricking sensation whenever pressure is made upon it the localisation of a stone in the ureter is pretty clear. So is it if, with the symptoms of stone in the kidney, or with frequent and painful micturition, a hard body is felt in the course of the ureter by vaginal or rectal palpation, or by digital examination or sounding of the bladder. On cystoscopic examination the mucous membrane around the ureteral orifice may be seen discoloured from extravasated blood when a calculus is impacted at the lower end of the ureter.

Through the roof of the vagina a calculus can be felt at any spot within the last two and a half or three inches of the ureter and could be removed therefrom without opening the peritoneum. Through the rectum not more than one and a half inches of the ureter is thus under control. In Rawdon's case the calculous mass felt through the rectum gave the impression of being fixed to the posterior wall of the bladder. The lower end of the ureter contained a cretaceous substance and two calculi; the lower calculus was of the size of a date-stone and was close behind the ureteral orifice.

The passage of a calculus along the ureter should be suspected if attacks of pain and hæmaturia and other symptoms suggestive of renal calculus have extended over several days or weeks or months, and if with each succeeding attack the pain and tenderness on pressure are located lower and lower down along the course of the ureter, and the bladder at length becomes the seat of pain and irritability. So also should suspicion be aroused if, after one or more attacks of typical renal colic, the patient is suddenly seized, after walking or some exertion, with a violent pain shooting along the course of the ureter and followed by settled pain and great tenderness at one particular spot in this course, lasting days or weeks uninterruptedly. I bave related a very typical case of this kind in my Hunterian Lectures on the Origin and Progress of Renal Surgery (1898, p. 77).

The severity of the pain and hæmaturia and the subsequent effect upon the kidney depend upon the character of the stone more perhaps than upon its size. A small calculus with a rough or angular surface does the greatest harm and is less likely to pass than a smooth uric acid calculus of much larger size; it is more prone to stick into the wall of the ureter and cause oedema, inflammation, or ulceration. Fig. 7

FIG. 7.

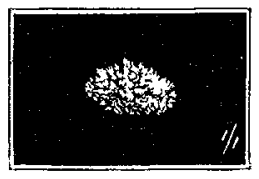

Calculus removed by ureterclithotomy impacted two pelvis (author's case) shows the natural size of a minute calculus which I removed from the ureter of a woman two inches below its junction with the renal pelvis. It had given rise to six months of continuous discomfort, aggravated by the most severe attacks of pain and hæmaturia. Rest gave relief, but on one occasion after a period of three weeks in bed the first walk across the bedroom induced a fresh attack. The calculus was very firmly fixed by its minute rough processes and had to be actually dug out of the ureteral wall. In this case hæmaturia was a very pronounced symptom.

As soon as impaction occurs in the ureter the symptoms will greatly depend upon whether or not the opposite kidney is healthy in structure and unbampered in function. If there is but one kidney or the two kidneys are fused and have only a single ureter, if the opposite kidney has been previously destroyed, whether by calculous, tuberculous, or some other disease, or if the two ureters are blocked simultaneously by calculi, anuria with all its alarming symptoms is the result.

A calculus of one and a half grains impacted in the ureter has been the cause of a fatal anuria in such conditions as those just mentioned. If the calculas is dislodged under the influence of accumulated pressure of urine, of opium or chloroform, or of the expulsive power of the ureter, the kidney may regain its secreting function and the effects of anuria may pass off. On the other hand, the poisoning effects of uræmia may be too severe to pass off with the escape of the stone, and death may result just as if the calculus had remained impacted. It is often stated that anuria is in some instances produced by a calculus, lodged in one ureter, causing a reflex suppression-i.e., producing a complete inhibitory effect upon the opposite kidney. It is doubtful, however, whether such an effect, if it ever occurs, lasts more than a few hours when the opposite kidney is structurally quite healthy

A persistent abdominal tumour on the same side as the impaction, due to nephrectasis, is an occasional symptom of ureteral calculus.

An intermittent abdominal tumour due to hydronephrosis - i e., a tumour preceded by a diminution in the quantity of urine passed, and the subsidence of which is accompanied and followed by a largely increased discharge of urine-has of late years become a recognised symptom of renal obstruc. tion due to calculus, moveable kidney, ureteral valve, or ureteral stricture.

Nepbrectasis is very apt to occur in those cases in which the calculas is in the upper end of the ureter and from time to time slips back again into the dilated renal pelvis. It must not be forgotten, however, that very considerable atrophy of the renal parenchyma with considerable dilatation of the renal pelvis and calyces (nephrectasis) is often present without any evidence of a tumour ascertainable by palpa. tion of the abdomen. Another indication of hydronephrosis, whether associated with an abdominal swelling or not, is the occasional diminution in the amount of urine associated with renal pain, followed after a variaiole pericd of days or weeks by relief of the pain when a greatly increased quantity of urine is passed. Periodical dis. charges of pus point to pyonephrosis. The late Dr. Habershon ${ }^{5}$ recorded a typical case of this kind. A man, aged 64 years at the time of his death, had from the age of 16 years suffered from periodical discharges of pus. Each discharge was preceded by the formation of a large rightsided abdominal swelling and was followed by the disappearance of the swelling. After death a calculus was found blocked in the right ureter and several pints of pus distended the pelvis of the right kidney the rpper part of which was the seat of a cancerous new growth.

The urine may contain some or other of the following deposits-crystals, fragments of calculus, fibrous coagula, blood, blood-casts of the ureter, and pus. In some cases blood and pus have been found together in small or moderate amounts, in others there has been severe hæmaturia, and in others, generally cases of long standing, there have been large discharges of pus.

Prolapse of the ureter into the cavity of the bladder, and in the female even through the urethral orifice as far as the vulva, is one of the rarer effects of calculus impacted in the ureter. $^{6}$ Its presence should at once suggest the probability of ureteral calculus.

PROGNOSIS.

1. As regards the kidney.-This is very unfavourable. If the obstruction is complete and the ureter remains blocked either by the calculus itself or by a stricture caused by the cicatrisation of an ulcer or slough due to the damage wrought by the calculus while impacted, the kidney after many months becomes converted into a small fibrous mass or small sac. If the calculus after a while, even after four or five months, should be dislodged and the ureteral channel opened up again, the kidney, though damaged, may become repaired. If the obstruction is not complete dilatation with atrophy of the renal substance is sooner or later the consequence in most instances, and if any septic condition of the urinary organs arises pyonephrosis and suppurative

5 Transactions of the Clinical Society of London, vol. xiii., p. 141

See Transactions of the Pathological Society of London, vol, xiv., p. 185 , and vol, $x \times x .$, p. 310 . 
pyelonephritis supervene. Cancer of the obstructed kidney has been met with associated with impacted ureteral calculus of many years' standing. (Habershon, Morris.)

2. As regards life. - This depends on the condition of the opposite kidney. If healthy the unobstructed kidney will become hypertrophied and will perform the additional function demanded of it in a manner consistent with excellent and prolonged life; and if the kidney involved simply atrophies all may go well with the patient if he does not subsequently form a fresh calculus in the healthy kidney, as in many instances is the case. If, on the other hand, the kidney involved undergoes active inflammatory and suppurative changes, life is jeopardised thereby, and the prognosis then depends upon the promptitude of surgical treatment and the resisting and reparative powers of the patient. If the ureteral wall has been much damaged by the prolonged pressure or laceration caused by the calculus, extravasation of urine may occur into the retro-peritoneal cellular tissue and abscess or diffused suppuration may result. ${ }^{7}$ If the opposite kidney is defective, obstructed, or absent, complete suppression of urine is the consequence of ureteral impaction, the patient becomes comatose and dies within some days or weeks from the date of impaction. If the loss of the function of both kidneys is not quite complete the patient may survive a little longer, pass daily small quantities of urine mingled with blood and perhaps pus, become very ill with fever and diarrhœa, and die in a typhoid state at the end of several weeks. (Bence Jones.)

\section{Pathological EFfects.}

On the ureter.-Above the obstruction the ureter may become thinned out by eccentric pressure and stretching, or cedematous, inflamed, or ulcerated, or it may be dilated and sacculated, and more or less tortuous. The dilated ureter may rupture, bursting as the urethra bursts behind a stricture ${ }^{8}$ but usually the ureter becomes thickened as well as dilated from ureteritis. Stricture of the ureter may follow ulceration or a slough at the site of impaction. Below the obstruction the ureter may be very little if at all changed, or part or the whole length of it to the bladder may be thickened and stenosed or converted into a mere fibrous cord. The whole ureter has been met with converted in to an impervious cord when a stone had blocked the upper end. The mucous membrane of the bladder around the ureteral orifice is sometimes greatly discoloured from extravasated blood when the ureter is plugged by a calculus at its lower end. A stone impacted in the lower extremity of the ureter may escape into the bladder by setting up ulceration; or after pouching or rupturing the inter-vesical ureteral wall it may cause the mucous membrane of the bladder to project in a cyst-like and more or less pendulous manner; or the lower end of the ureter, whether ur not containing the calculus, may be prolapsed into the bladder with the ureteral orifice reduced to the size of a pinhole and situated on the summit of the prolapsed swelling.

The calculus is less likely to ulcerate or rupture into the cellular tissue behind the bladder because of the greater thickness of the bladder wall on the outer than on the inner aspect of the ureter. For three-quarters of an inch the ureter traverses the bladder wall, having the muscular coat on the outside and little more than the mucous membrane on the inside of it. As stated previously, Spencer Wells met with a case in which a urinary calculus was dislodged per rectum after a periprostatic abscess, and he conjectured that perhaps the calculus had never been in the bladder but had passed from the ureter backwards. ${ }^{9}$ Cancer of the lower end of the ureter extending to the bladder bas supervened on impaction of a calcium oxalate stone in the lower end of the ureter. ${ }^{10}$

On the kidney.-The kidney may undergo chronic changes and its calyces and pelris may be dilated. It may be rendered anæmic, œdematous, and enfeebled and converted into a shrivelled mass of fibrous tissue; or into a polycystic condition (Fig. 8); or be entirely destroyed, shrunken, and reduced to an aggregation of pouches (Fig. 10) with no true renal tissue left; or be converted into a thin-walled sacculus containing limpid urine without pus or micro-organisms ; or into a thick-walled cyst with thick, tough fibrous partitions, containing many ounces, or even a

7 See case recorded in my Hunterian Lectures, p. 77.
8 Morgagni and Velpeau's Surgery 1851 p. 1021 see Transactions

of the Pathological Society of London, vol. xri., p. 1761 ; see also

St. Bartholomew's Museum, No. 2356.

9 Transactions of the Pathological Society of London, vol. v. p. 202 10 Brit. Med. Jour., Oct. 18th, 1884, p. 758 . pint or two of pus and with no remains of proper secreting tissue. There is sometimes great thickening as well as dilatation of the renal pelvis and calyces; and with atrophy of the secreting structure there may be great thickening of the fibrous capsule and great increase in the interstitial tissue of the kidney, so that the organ looks to be hypertrophied as well as sacculated. The interior may be filled with pus, dense walls of tough fibrous tissue separating the calyces and sometimes shutting one or more off entirely from the rest. In fact, the kidney may be in any stage of hydroor pyonephrosis. When occupied by a large abscess or dis.

FIG. 8.

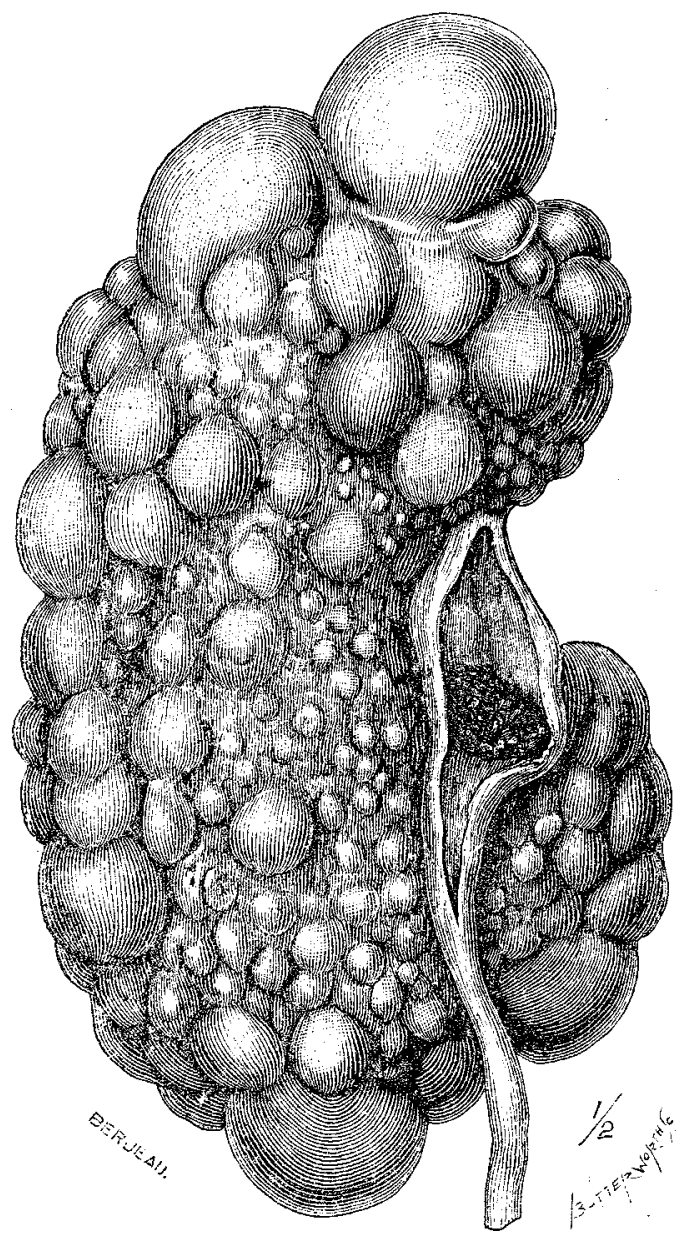

Polycystic kidney with reval calculus impacted in the upper end of the ureter. Guy's Hospital Museum, No. 1607.

tended by pyonephrosis a fistulous communication may form with the surface in the loin or groin (Fig. 9); or may pass through the diaphragm and establish an empyema; or may open into the colon or stomach ; or may cause diffused perinephritis and retro-peritoneal suppuration. In the cases which I have met with of impacted ureteral calculus where the kidney has thus given way and caused fistula or perinephritis there have been calculi present in the kidney also. The kidney has in rare cases become the seat of carcinoma, as stated before.

On the peri-ureteral tissue.-This may become the seat of inflammation and even of abscess or diffused suppuration resulting in fistula. The lumbar region, the groin, the cavity of Retzius, and the peri-prostatic regions have been the situations of abscess or fistula. Fibro-lipomatous changes are frequent.

\section{TREATMENT}

If symptoms continue giving rise to a suspicion of an impacted ureteral calculus, or if attacks of pain, hæmaturia, and pyuria recur after complete rest and the trial of the usual medicinal treatment, the ureter ought to be explored. If a calculus is known to be blocking the ureter it ought to be removed without delay by one of the methods of extra-peritoneal ureterotomy if it cannot be extracted through the renal pelvis. There is no medicinal treatment which is of any use or which affords any hope of saving life or the integrity of the kidney when a stone is impacted in and not simply passing down the ureter. If not effected in a few hours its passage should be assisted or the stone remored by operation; there is great danger to 
the kidney and even to life by delay, especially if active of lumbar uretero-lithotomies, and in the nephrectomy, symptoms continue. On the other hand, extra-peritoneal uretero-lithotomy is higbly successful and will probably become almost as uniformly so as nephro-lithotomy. Velpeau, before 1851, satisfied himself upon the dead body that he might have removed a calculus of the size of a nut through the flank from the abdominal part of the right ureter of a patient under his own care. Gigon of Angouleme in 1856 described every detail of the modern operation of uretero-lithotomy which he proposed to perform, but did not carry out, in a case of his own. In justice to myself, and with reference to many remarks which have been made by writers who have had only my article published in 1884 to go by, I ought to add that in 1885 , without then having had the opportunity of carrying is into effect, I recommended uretero-lithotomy in any part of the course of the ureter for impacted stone. In a private letter written on Sept. 8th, 1885, to Mr. Mlbert Dunlop, surgeon-superintendent of the

FIG. 9.

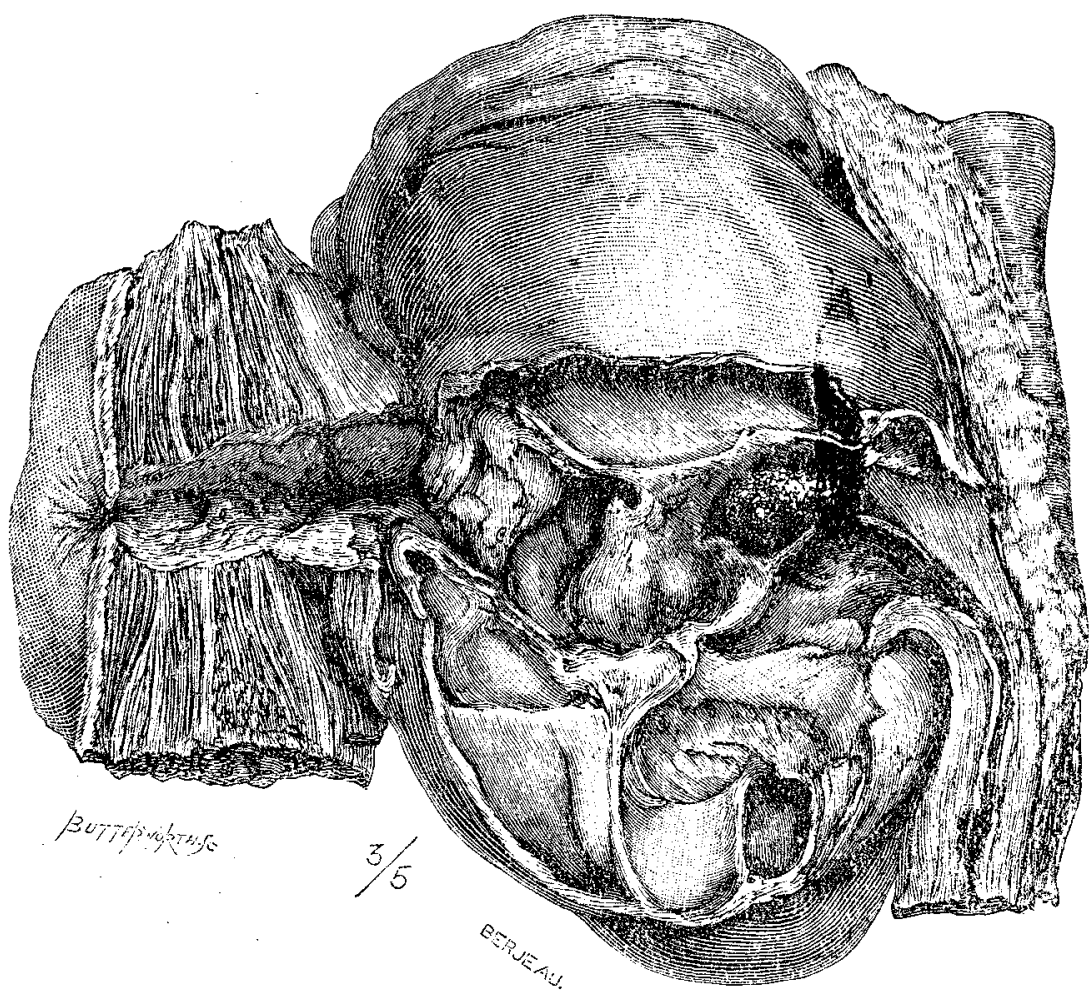

Calculus impacted in the upper end of the ureter. The kidney is destroyed. The ureter is thickened by chronic inflammation. An abscess has made its way to the surface and left a sinus opening on the loin. St. Bartholomew's Hospital Museum.

Ipswich Hospital, Queensland, in answer to a letter asking my advice as to a case in which he had explored the kidney of a girl, aged 20 years, with negative result, I wrote: " Either explore the kidney through the loin again and incise the kidney and examine its cavity with the finger and the ureter with a sound or make an examination of the kidney and ureter from within the peritoneal cavity. If a stone be found in the ureter cut it out from behind the peritoneum and apply continuous sutures to the ureter, if it cannot be pressed downwards into the bladder whence it can be removed through the urethra. Either of the above should be tried before resorting to nephrectomy."

The accompanying table contains a list of 46 completed operations performed on account of ureteral calculus. In but very few of them, however, had an accurate diagnosis been arrived at beforehand. The character of the operations differed greatly. In four cases nephrectomy was performed; in one of these cases, as it proved, the calculus was on the opposite side. In nine cases the operation was nephrotomy, the ureteral calculus having been removed through the incision of the renal substance by pushing it upwards, after failure or otherwise in finding a stone in the kidney itself. In four cases pyelotomy was performed, the stone being pushed up and removed through the renal pelvis. In 29 cases uretero-lithotomy was the method, in four by the trans-peritoneal, in 25 by an extra-peritoneal routes. Of the 25 extra-peritoneal uretero-lithotomies one was rectal, two were vesical, four vaginal, 12 through a lumbar and six through an iliac or inguinal incision. In the 12 cases nephrotomy, and pyelotomy cases the operation was undertaken primarily with the object of exploring the kidney. In other words, in 28 out of 44 cases an operation was performed in the expectation that the disease was renal ; in 25 of them the calculi were accessible and removed through the lumbar incision; in three the kidney was so diseased as to lead to nephrectomy. In one of the four nephrectomy cases the abdominal route was chosen as the kidney was bydronephrotic and formed a large abdominal tumour. In one of the nephrotomy cases the calculus was diagnosed through a previous laparotomy exploration. Of the iliac cases diagnosis had been made by laparotomy previously performed in three; in another the position of the stone was ascertained by vaginal palpation; in another by catheterising the ureter tbrough the loin, and in the sixth case the kidney had been twice explored through the loin and calculi remored at the irst operation. It is clear from this analysis that in the great majority of cases a lumbar operation will be the right practice to adopt.

Whether the stone is extracted through the loin, groin, sacral, vaginal, pre-rectal, or vesical ronte will depend on the part of the ureter in which it is lodged. It is safer to remove it by an extraperitoneal rather than a trans-peritoneal operation, even when its existence and location have been determined by an intra-peritoneal search. If it is uncertain in which ureter the stone is it is better to examine each through a lumbar incision than by laparotomy. If during an exploratory laparotomy calculus should be found impacted in the pelvic section of the ureter it should be displaced either upwards above the brim of the pelvis or down wards into the bladder, but it may hare to be left for a time in the ureter. Nothing should induce the surgeon to incise a ureter through the peritoneum unless he is absolutely sure of the aseptic state of the urine. He should close the peritoneum and then and there remove the calculus by the retro-peritoneal method, or postpone the removal till the patient has recovered from the laparotomy. There should be no hesitation on this point, for with a calculus blocking the ureter it is impossible to be sure that the urine is aseptic. Indeed, the great probability, to say the least, is that it is not so. Granting that the wound in the ureter has been carefully sutured after a trans-peritoneal ureterotomy (a task by no means easy of accomplishment in the depths of the pelvis) and that the peritoneum has been replaced over the ureter and stitched in position, there can be no absolute security, with septic urine in contact with the wound, that union will follow, and extravasation, and septic peritonitis not be the consequence.

In all cases the calculus should, if possible, be displaced by gentle pressure upwards and removed through an opening in the ureter a little away from the point at which it has been lodged. Here the coats are more likely to be less severely diseased and the ureterotomy wound can be more easily sutured and will be more likely to repair well than a wound at the seat of impaction would be This practice is of great importance when the stone is below the brim of the bony pelvis, as by displacing the stone upwards it can very readily be removed through the lumbo-iliac incision and the vaginal or the more serious and complicated sacral operation is thus avoided.

When the ureter is blocked near its upper end the calculus, if of a smooth surface and readily moved, should be pushed upwards into the renal pelvis and thence extracted. But this cannot always be safely done, and if the stone is of oxalate of lime and very rough on its surface its inequalities stick into the wall and may cause tearing of the mucous lining of the ureter if any attempt is made to displace the stone upwards. I have had experience of the tenacity with which a small rough stone will attach itself to the ureteral walls. Other surgeons have failed in their endearours to dislodge a stone and others again have only succeeded with difficulty and with the hand in the peritoneal cavity (Hall and Lane). In one of Israel's cases the ureter was torn from the renal pelvis during the attempt. In Torrey's case the ureter was torn during an attempt to dilate it. 
In a good many cases when the kidney is explored a calculus is found at the junction of the ureter and infundibulum, but very moveable, falling into the ureteral orifice and back again into the renal pelvis like a ball valve; such a calculus should be pushed up in to the renal pelvis before being removed, as the incision in the renal pelvis can readily be, and should be, closed by sutures. There is no reason to cut the renal parenchyma for the extraction of a stone so placed, although this has been done in several recorded cases. The length of the incision in the ureter will be in proportion to the size of the calculus and should be free enough to allow of its extraction without contusing the edge of the wound in the ureter. The calculus may be assisted out by forceps or a blunt probe or curette. A ureteral catheter should then be passed through the wound along the duct to the bladder below and kidney above so as to make sure of its permeability. If a second calculus is detected an effort should be made to work it gently towards the wound in the ureter; if this is not possible a second incision into the ureter at the place of the second obstruction should be made at the time of the operation if the patient is in a condition to bear a prolongation of the anæsthetic and the shock attending an extension, perhaps a considerable extension, of the original wound or perhaps the adoption of another route to the ureter. Otherwise the second stone must be removed at another time; in that case if the original operation had been undertaken on account of calculous anuria, as the second calculus will be situated lower down, a fistulous opening would have to be maintained until the remaining obstruction had been successfully removed.

Extraction of a stone impacted in the resical part of its course or in a ureteral pouch should be effected per urethram in the female and by perineal or suprapubic cystotomy in the male. This method was advocated by me in

FIG. 10.

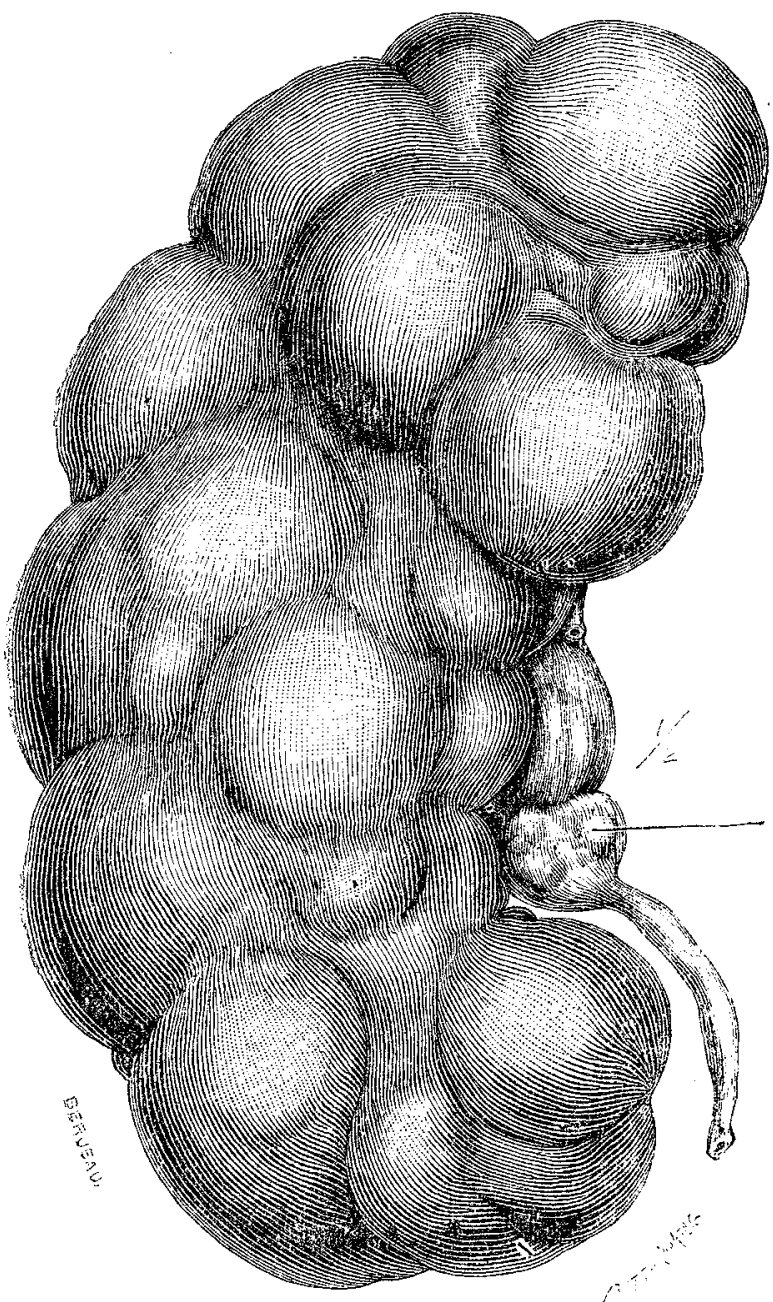

Disorganised kidney from obstructing of the upper end of the constricted ureter by a stone lodged above the constriction (author's case).

1884, before the first edition of my book was published, and is said to have been practised by Desault and Garengeot. Unless the patient is very thin and the pelvis shallow the suprapubic operation is to be preferred to the perineal. Tuffier has remored a ureteral calculus in this manner.
If the calculus is projecting at the ureteral orifice into the bladder it should be drawn out by a lithotrite or forceps or pressed out by the finger in the bladder, assisted by the fingers of the other band in the vagina or rectum pressing the stone forwards; if this cannot be done the mouth of the ureter and the mucous membrane covering the calculns may have to be incised. If the incision is limited to the tissue covering the calculus on the surface towards the interior of the bladder there should be no fear of injuring the peritoneum or cellular tissue behind the bladder. A small scoop or curette may assist the process of disengaging the stone from the ureter. Whilst using the scoop as well as making the incision the left forefinger in the vagina or rectum should prevent the calculus from slipping away from the ureteral orifice and so being pushed further up the duct, a thing not unlikely to happen, as the ureter will probably be dilated behind the stone.

If stenosis or a stricture of the ureter is present as well as a calculus (Fig. 10) it ought to be treated at once after removing the calculus by the method described in a paper by me in THE LANCET of July 1st, 1899, otherwise nephrectasis or a fistula will persist after the operation.

Cavendish-square, $\mathrm{W}$.

\section{EARLY $v$. LATE OPERATION IN CASES OF INFLAMED APPENDIX.}

BY C. MANSELL MOULLIN, M.D. OxON., F.R.C.S. ENG., SURGEON AND LECTURER ON SURGERY AT THE IONDON HOSPITAL.

IT is now a little more than 10 years since Sands, operating within 48 hours of the beginning of the attack, performed the first successful laparotomy for peritonitis consequent upon perforation of the appendix. It is just 10 years since the first series of early operations was reported by McBurney, seven out of eight patients recovering. Since that time, more especially since McBurney's paper containing a report of 24 early operations, 23 of which recovered, was read before the New York Medical Society in 1891, it has become recognised that in a large proportion of these cases operation is the only treatment possible. The general principle is admitted everywhere; but with regard to detailswhether the patient should be operated upon during the first attack or soon after it or whether he should be allowed to run the risk of a second and even of a third attack, and especially as regards the time when the operation should be performed-there is great divergence of opinion.

In America it is generally held that laparotomy is advisable as soon as the diagnosis of progressive inflammation of the appendix is certain. Even if the progressive character of the attack is doubtful it is better to err on the side of safety. Any case, whether in its first attack or not, which shows definite signs of increasing disease 36 hours after the beginning, should be operated upon without further delay. In Germany Carl Beck and others who have written recently upon this subject hold the same view. It is better to operate too early than too late according to Strümpell. But in England neither early operation nor operation during or after the first attack is in favour. Unless the symptoms are so imperative that delay is out of the question it is better to wait at least until the fifth day. Both of these views cannot be correct, the difference between them is far too great. If it is right to wait until the fifth day in all but absolutely imperative cases it is wrong to make a rule of operating at the end of 36 hours. One or other, or perbaps both, must be modified.

It is worthy of note that the two recognised authorities on the pathology of this question, Hawkins and Kelynack, do not speak by any means strongly in favour of delay, but rather the reverse. Hawkins concludes that if all his relapsing cases (59 out of 264) had been operated upon during or immediately after the first attack seven lives would have been saved and 52 other individuals would have been spared a more or less severe illness, provided, of course, that these 59 early laparotomies had terminated favourably. "If the mortality of the operations is so small that it may be neglected, and if $I \mathrm{am}$ wrong in doubting its efficacy in preventing fatal peritonitis, it must then be admitted that excision in the first two days of illness is the true and rational plan of treatment." And Kelynack, after mentioning cases 